\title{
Method parameters' impact on mortality and variability in rat stroke experiments: a meta-analysis
}

\author{
Jakob O Ström ${ }^{1 *}$, Edvin Ingberg ${ }^{1}$, Annette Theodorsson ${ }^{1,2}$ and Elvar Theodorsson ${ }^{1}$
}

\begin{abstract}
Background: Even though more than 600 stroke treatments have been shown effective in preclinical studies, clinically proven treatment alternatives for cerebral infarction remain scarce. Amongst the reasons for the discrepancy may be methodological shortcomings, such as high mortality and outcome variability, in the preclinical studies. A common approach in animal stroke experiments is that A) focal cerebral ischemia is inflicted, B) some type of treatment is administered and C) the infarct sizes are assessed. However, within this paradigm, the researcher has to make numerous methodological decisions, including choosing rat strain and type of surgical procedure. Even though a few studies have attempted to address the questions experimentally, a lack of consensus regarding the optimal methodology remains.
\end{abstract}

Methods: We therefore meta-analyzed data from 502 control groups described in 346 articles to find out how rat strain, procedure for causing focal cerebral ischemia and the type of filament coating affected mortality and infarct size variability.

Results: The Wistar strain and intraluminal filament procedure using a silicone coated filament was found optimal in lowering infarct size variability. The direct and endothelin methods rendered lower mortality rate, whereas the embolus method increased it compared to the filament method.

Conclusions: The current article provides means for researchers to adjust their middle cerebral artery occlusion (MCAo) protocols to minimize infarct size variability and mortality.

Keywords: Brain infarction, Middle cerebral artery occlusion, Rats, Methods, Mortality, Variability

\section{Background}

Ischemic stroke is amongst the leading causes of death and disability in the world and has been the subject of massive research efforts during recent years. Even though these efforts have resulted in more than 600 treatments reported effective in preclinical studies [1], clinically proven treatment options are still few. There are reasons to believe that this apparent translational roadblock may inter-alia be due to methodological confounding factors, including high mortality and large outcome variability, in the preclinical studies [2-4].

The usual approach in experimental stroke studies, used in hundreds of publications each year, is that A) focal cerebral ischemia is inflicted in rodents [5,6], B)

\footnotetext{
* Correspondence: jakob.strom@liu.se

${ }^{1}$ Department of Clinical and Experimental Medicine, Clinical Chemistry,

Faculty of Health Sciences, Linköping University, County Council of

Östergötland, Linköping, Sweden

Full list of author information is available at the end of the article
}

some type of treatment is administered and C) the infarct sizes are assessed. Even though this setup may seem straight forward, there are infinite numbers of methodological variants, and there is a profound lack of consensus regarding the ideal methodology to be used in experiments of this kind. A small number of studies aiming to optimize the infarct induction regarding the important aspects of mortality and variability, for example by testing various rodent strains and sizes [7-9], surgical procedures [10-13] or occluding intraluminal filaments [14], have been published. However, these studies have rendered conflicting results, and are too few and too small to provide comprehensive understanding of how the different methodological parameters interact.

Hence, it was thought of interest to investigate the influence of different methodological factors on infarct variability and mortality in rat stroke models using a hypothesis-driven meta-analytical approach where their
C Biomed Central 
interactions and complexity could be embraced rather than disregarded. The meta-analytical approach seemed attractive since such a vast number of studies with the abovementioned experimental setup are published, and since control/vehicle/placebo groups (hereby referred to as "control groups"), suitable for inter-study comparisons, are almost invariably included. A study of this kind has, to the best of our knowledge, not been published previously. Even though other animals, not least mice, are also well-used in experimental stroke research, rats were due to space restrictions chosen to be the sole focus of the current article.

The aim of the current meta-analysis was to investigate chosen methodological variables' effects on infarct size variability and mortality. An a priori hypothesis of six main factor-outcome relations (1A-3B) was established:

1. Rat strain affects (A) infarct size variability and (B) mortality.

2. Type of focal ischemia procedure affects (A) infarct size variability and (B) mortality.

3. In studies using the intraluminal filament method, the type of filament affects (A) infarct size variability and (B) mortality.

\section{Methods}

\section{Article inclusion}

To identify articles to be included in the meta-analysis, Medline was searched with the line (mcao or "middle cerebral artery occlusion" or "MCA occlusion" or "stroke" or "cerebral ischemia" or "brain ischemia") and (rat or rats), resulting in more than 19,000 hits. Starting with the latest article the $10^{\text {th }}$ of June 2011 [15], the articles were consecutively, in order of PubMed identifier, assessed for inclusion in the study.

The inclusion criteria were:

A. Article written in English

B. Original research article

C. Experiments performed in living adolescent, adult or elderly rats

D. Animals inflicted one single focal cerebral ischemic lesion

E. Infarct size assessed and results presented

F. Inclusion of a control group, untreated except for vehicle treatments

G. Sufficient description of fundamental aspects of the experiment (after e-mail correspondence)

\section{Data extraction}

Data about the control groups were extracted from all included articles. If an article included more than one control group, differing in for example euthanasia timepoint, all control groups were separately included and assessed independently of each other. When extracting the method data, we adhered strictly to the principle "If it is not described, it was not performed". Registered factors and outcome measures are listed in Table 1.

Because many of the included articles/control groups lacked information about for example mortality rate, the researchers of those articles were contacted via e-mail with a gentle request to provide this information. In total, the authors of 310 articles were e-mailed, of which 183 (59\%) complied.

Since power calculations for large multiple regression analyses are extremely complex to perform a priori, a saturation principle was adopted to determine a sufficient number of control groups to be included. After information from 300 control groups had been extracted, an interim analysis was performed, and then re-performed every 40-50 new control groups included. When the results had stabilized (no changes in overall trends, and only minor changes in p-values), no more articles were included. 502 control groups from 346 articles were finally included in the study [11,15-359] while 1084 articles were excluded (Figure 1).

\section{Processing of data \\ Category refinement}

After extraction of data, categories represented by less than 5 control groups (corresponding to less than $1 \%$ of the material) were included in the Others-categories. This approach was motivated by the fact that these small categories otherwise would run the risk of being attributed high explanatory values that were not statistically substantiated, thus obscuring the influence of other categories.

In the Other strain category, the following variants were included: Long Evans rats, T-cell deficient nude rats, SHRSP, Fischer rats, Zucker rats, Hooded Wistar rats, Lewis rats, Holtzmann rats and Swiss albino rats.

The variable Sex finally contained four categories, since males formed the first category, females that were not explicitly ovariectomized were separated from ovariectomized females in a second and third category, and control groups using mixed or unspecified animals were grouped in a fourth category.

Fifteen various anesthesia regimens were reduced to four main categories and one Others category (in which for example methohexithal sodium, medetomedin and unspecified regimens were included). All inhalation anesthetics (isoflurane, halothane, sevoflurane, fluothane and enflurane) were included in the first category, while chloral hydrate was used frequently enough (and was not appreciably similar to any other category) to deserve a category of its own. The third category, Ketamine, included all ketamine containing regimens, such as ketamine/ xylazine, ketamine/rumpun or ketamine only. Finally, all 
Table 1 Extracted factors and outcome measures

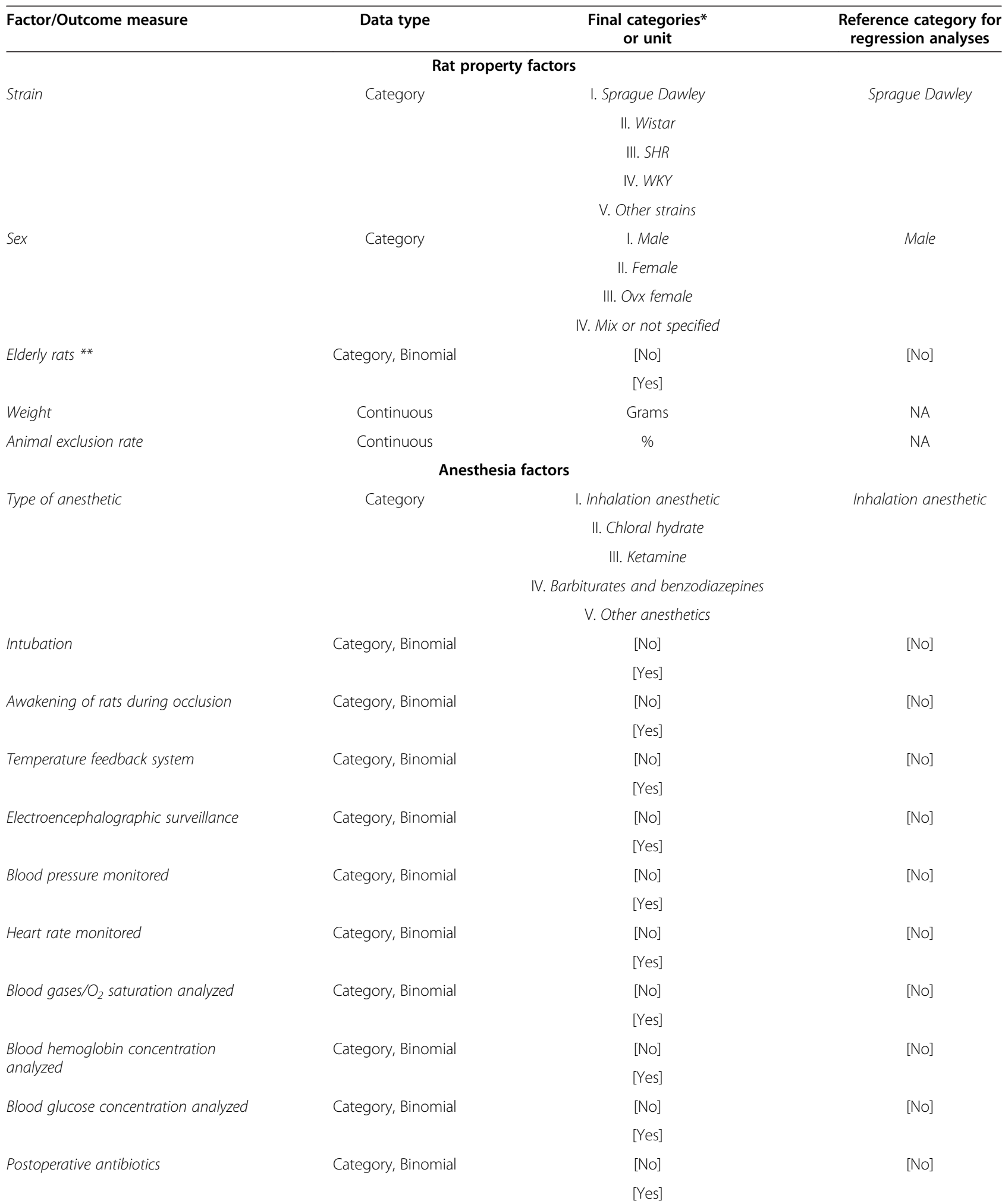

Focal ischemia procedure factors 
Table 1 Extracted factors and outcome measures (Continued)

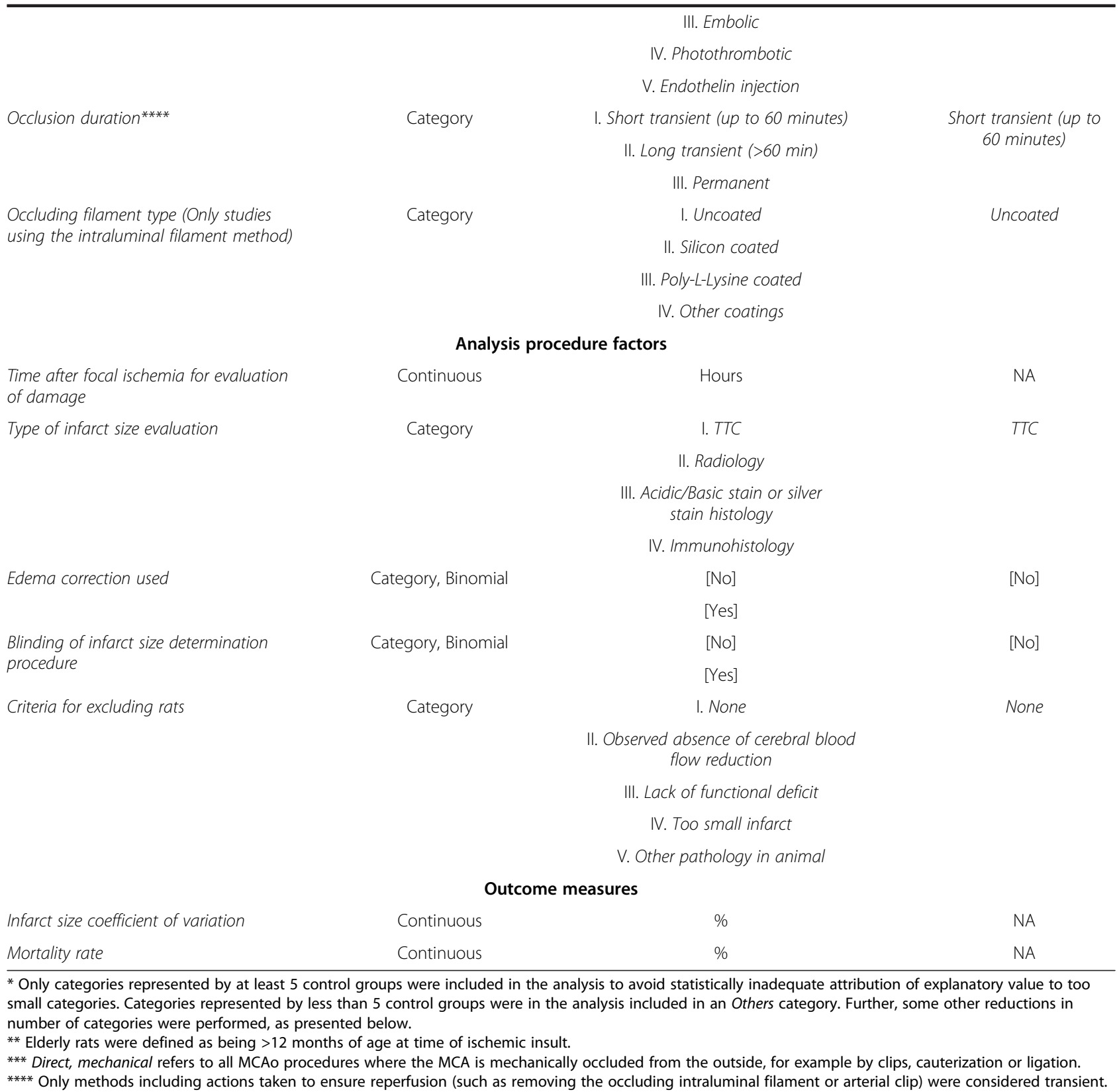

anesthetic regimens pertaining to the barbiturate or bensodiazepine groups, such as pentobarbital and diazepam, formed a fourth category.

The variable Blood gases $/ \mathrm{O}_{2}$ saturation analyzed was initially registered as the separate variables $\mathrm{Blood} \mathrm{pH}$ analyzed, Blood oxygen saturation analyzed and Blood carbon dioxide analyzed, however these three were so highly correlated that they were thought better to be represented by only one variable.

Regarding the techniques for causing focal ischemic lesions, all intraluminal filament procedures were reduced to one single category. All direct occlusion techniques, based on craniectomy followed by physical occlusion of the MCA by means of a clip, suture, hook or cauterizer, formed the Direct category, while emboli techniques were clumped up in a third category. Photothrombotic procedures and methods of endothelin injection defined the fourth and fifth categories, respectively. It should however be noted that the occlusion time was accounted for in another variable and that the choice of different filaments were analyzed separately.

The filament categories, used for the analyses addressing hypotheses $3 \mathrm{~A}$ and $3 \mathrm{~B}$, were also reduced. The uncoated filaments, a seemingly homogenous group, formed the 


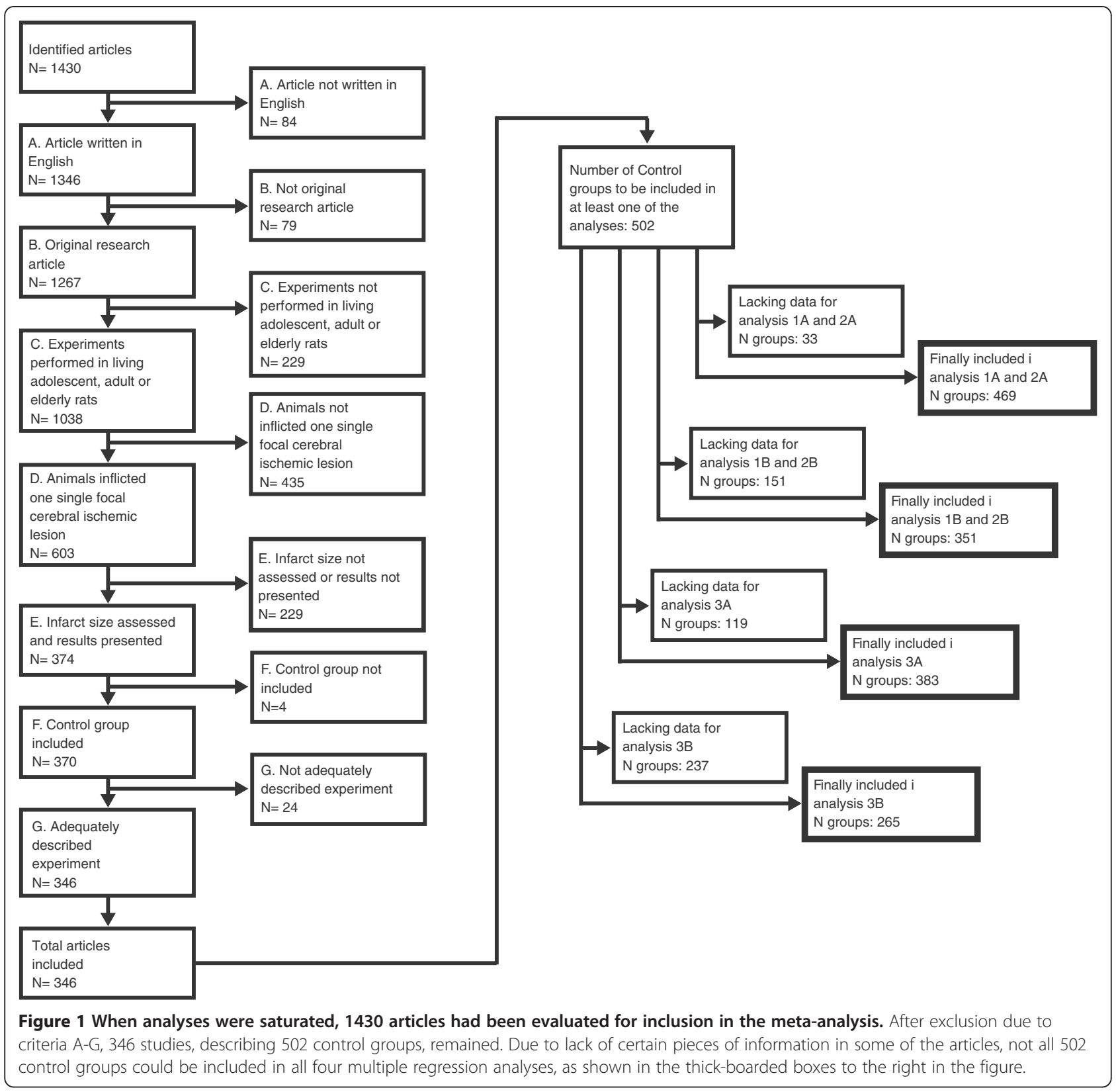

first category, while silicone and resin coating were put in the Silicone category. Poly-L-Lysine formed a category of its own, while other rare coating techniques (including for example heparin coating, "glue coating" and paraffin coating) were put in a separate category together with unspecified coating techniques.

The procedures used for infarct evaluation were reduced to four categories. The most frequently used technique, 2,3,5-triphenyltetrazolium chloride staining, defined the first category, while radiologic methods (in the majority of cases magnetic resonance imaging, but in a few cases computed tomography) were put in a Radiology category. Various acidic/basic staining techniques (such as hematoxylin/eosin, cresyl violet and thionine) was, together with silver staining (used in only one of the included studies), included in category number three, while immunohistological methods were put in a fourth category.

Edema correction can be performed in different ways [360,361]. It was initially the intention to register not only if, but also which type of, edema correction was used. However, it soon turned out that this was not specified in a sufficient number of articles to perform a meaningful analysis. It was therefore only registered if edema correction had been used or not.

Concerning the exclusion procedures, the first category included all control groups in which no exclusion 
criteria were explicitly adopted. In the second category, control groups in which surveillance of blood flow reduction (for example using laser-doppler), with the plausible aim to exclude the absence of such, were put. The third, fourth and fifth categories contained control groups from articles in which lack of functional deficit, too small infarct size or other pathology (including intracerebral hemorrhage), respectively, were stated to be exclusion criteria. It should be noted that control groups from articles accounting for multiple exclusion criteria were registered in more than one of the exclusion categories.

\section{Definition of continuous variables}

Animal exclusion rate was defined as the percentage of rats excluded due to other reasons than mortality from induction of focal cerebral ischemia until the final infarct size assessment. Time after focal ischemia for evaluation of damage was defined as the time from cerebral blood flow obstruction until sacrifice. The outcome Infarct size coefficient of variation was defined as the standard deviation of the infarct volume divided by the average infarct volume. Irrespective of how the infarct size is presented; as percentage of the whole brain, as percentage of the hemisphere or in cubic millimeters, this calculation provides a strictly defined, and inter-comparable, measure of the infarct size variability. The other outcome, Mortality, was defined as the unintended mortality in the control group, from induction of focal cerebral ischemia until infarct size assessment, as a percentage of the whole group.

\section{Statistical analyses}

A priori, six main hypotheses (1A-3B) were put (as aforementioned):

1. Rat strain affects (A) infarct size variability and (B) mortality

2. Type of focal ischemia procedure affects (A) infarct size variability and (B) mortality.

3. In studies using the intraluminal filament method, the type of filament affects (A) infarct size variability and (B) mortality.

Obviously, several additional hypotheses could be tested in the information compiled from the studies, but the higher number of hypotheses, the higher the risk of finding falsely significant results due to multiple comparisons (type I errors). However, due to the risk of type II-errors, corrections for multiple comparisons were not performed, calling for separate assessment of the six hypotheses.

All category variables were dummy-converted before analysis (Table 1). For categorical variables with more than two categories, the most common category was chosen to be the reference category. For binary variables, it does not matter which one is made the reference, why [No] (in other words, the lack of a specific methodological ingredient) was consistently chosen. The data were subsequently analyzed using multiple regression analyses with backward variable exclusion. This step identified which factors significantly affected the outcomes Infarct size coefficient of variation and Mortality, respectively. Next, an enter model, in which the variables from the backward procedure were complemented by lacking dummy variables, was performed (the enter models with the variables found significant in the backward analyses are presented in Tables 2 , $3,4,5)$. The analyses were weighted according to the number of animals used in each group; hence, a study including 5 animals in the control group was given less impact than a study including 20 animals. In total, four large multiple regression models (one for hypotheses $1 \mathrm{~A}$ and $2 \mathrm{~A}$, one for hypotheses $1 \mathrm{~B}$ and $2 \mathrm{~B}$, one for hypothesis $3 \mathrm{~A}$ and one for hypothesis $3 \mathrm{~B}$ ) were set up, testing the combined effects of all available factors on the respective outcome measure (Infarct size coefficient of variation or Mortality rate). Hence, all models controlled for the factors listed in Table 1 when testing the stated hypotheses. All statistical calculations were performed in SPSS (Version 20, IBM Corporation, Armonk, NY, USA). P-values $<0.05$ were considered statistically significant. Data were presented as mean \pm standard deviation or, when presenting results from the meta-analysis, with 0.95 confidence interval shown within brackets. It should be noted that the percent changes (regression coefficients) in Infarct size coefficient of variation and Mortality rate are presented in absolute, not relative, terms. In other words, if a certain variable decreases Mortality rate with $10 \%$, it means that the mortality would decrease from for example $40 \%$ to $30 \%$, and not merely from $40 \%$ to $36 \%$.

\section{Protocol violations}

It was originally planned to include the variable Exclusion rate to control for this confounder; however, too few articles presented the needed information. Even after all persistent e-mail correspondence, such a high number of studies lacked this variable that including it would have seriously hampered the analyses' power. The variable was therefore omitted.

Electroencephalographic surveillance was only utilized in one of the included studies, and this variable could thus not be analyzed. It was therefore omitted.

\section{Results}

Impact of rat strain on infarct size coefficient of variation and mortality: Hypotheses 1A-B

Strain significantly affected both Infarct size coefficient of variation and Mortality rate. Wistar had the strongest 
Table 2 Regression formula for hypotheses $1 \mathrm{~A}$ and $2 \mathrm{~A}$

\begin{tabular}{|c|c|c|c|c|c|}
\hline \multicolumn{6}{|c|}{$\begin{array}{l}\text { Regression formula for the effect of Strain and Type of middle cerebral artery occlusion procedure on Infarct size coefficient of variation } \\
\text { (hypotheses } 1 \mathrm{~A} \text { and } 2 \mathrm{~A} \text { ) }\end{array}$} \\
\hline \multirow{2}{*}{$\begin{array}{l}\text { Variable (reference category) } \\
\text { Constant }\end{array}$} & \multirow{2}{*}{$\begin{array}{c}\text { Variable categories } \\
\text { NA }\end{array}$} & \multirow{2}{*}{$\begin{array}{c}\begin{array}{c}\text { Regression } \\
\text { coefficient }\end{array} \\
23.1\end{array}$} & \multicolumn{2}{|c|}{$\begin{array}{l}0.95 \text { confidence interval } \\
\text { for regression coefficient }\end{array}$} & \multirow{2}{*}{$\begin{array}{r}\text { p-value } \\
0.002\end{array}$} \\
\hline & & & 8.3 & 38.0 & \\
\hline \multirow[t]{4}{*}{ Strain (Sprague Dawley) } & Wistar & -6.2 & -11.5 & -0.9 & 0.023 \\
\hline & SHR & -1.7 & -11.0 & 7.5 & 0.710 \\
\hline & WKY & 19.0 & -0.8 & 38.8 & 0.059 \\
\hline & Other Strains & 20.7 & 10.7 & 30.8 & 0.000 \\
\hline \multirow{4}{*}{$\begin{array}{l}\text { Type of middle cerebral artery occlusion } \\
\text { procedure (Intraluminal filament) }\end{array}$} & Direct, mechanical & 4.2 & -3.4 & 11.8 & 0.274 \\
\hline & Embolic & 14.7 & 3.4 & 26.0 & 0.011 \\
\hline & Photothrombotic & 10.1 & -5.2 & 25.5 & 0.196 \\
\hline & Endothelin injection & 23.1 & 9.3 & 36.9 & 0.001 \\
\hline \multirow[t]{3}{*}{ Sex (Male) } & Female & -0.6 & -19.7 & 18.5 & 0.951 \\
\hline & Ovx female & 2.3 & -16.7 & 21.4 & 0.810 \\
\hline & Mix or not specified & -11.5 & -21.5 & -1.5 & 0.024 \\
\hline Elderly rats & [Yes] & -23.6 & -39.6 & -7.7 & 0.004 \\
\hline Weight & [Continuous; Grams] & 0.1 & 0.0 & 0.1 & 0.001 \\
\hline \multirow[t]{4}{*}{ Type of anesthetic (Inhalation anesthetic) } & Chloral Hydrate & -11.5 & -16.9 & -6.1 & 0.000 \\
\hline & Ketamine & 2.9 & -4.4 & 10.2 & 0.430 \\
\hline & Barbiturates and bensodiazepines & -8.4 & -17.6 & 0.9 & 0.076 \\
\hline & Other anesthetic & -13.6 & -22.6 & -4.6 & 0.003 \\
\hline Awakening of rats during occlusion (No) & [Yes] & 8.8 & 0.9 & 16.7 & 0.028 \\
\hline Temperature feedback system (No) & [Yes] & -6.9 & -12.4 & -1.5 & 0.013 \\
\hline Blood hemoglobin concentration analyzed (No) & [Yes] & 10.9 & 3.0 & 18.8 & 0.007 \\
\hline \multirow[t]{2}{*}{ Occlusion duration (Short transient) } & Long transient & 1.9 & -3.9 & 7.8 & 0.519 \\
\hline & Permanent & -16.6 & -24.1 & -9.1 & 0.000 \\
\hline $\begin{array}{l}\text { Time after focal ischemia for evaluation of } \\
\text { damage }\end{array}$ & [Continuous; Hours] & 0.0051 & 0.0005 & 0.0096 & 0.030 \\
\hline \multirow[t]{4}{*}{ Criteria for excluding rats (None) } & $\begin{array}{c}\text { Observed absence of cerebral blood flow } \\
\text { reduction }\end{array}$ & -7.7 & -12.4 & -2.9 & 0.002 \\
\hline & Lack of functional deficit & -2.9 & -8.6 & 2.7 & 0.310 \\
\hline & Too small infarct & 0.1 & -9.6 & 9.9 & 0.981 \\
\hline & Other pathology in animal & 18.6 & 12.7 & 24.6 & 0.000 \\
\hline
\end{tabular}

Variables excluded by statistical software due to too low explanatory value: Intubation, Postoperative antibiotics, Blood pressure monitoring, Heart rate monitoring, Blood gases/O2 saturation analyzed, Blood glucose concentration analyzed, Type of infarct size evaluation, Edema correction used, Blinding of infarct size determination procedure.

negative regression coefficient, and rendered significantly lower variability $(-6.2 \%, 0.95 \mathrm{CI}:-11.5$ to $-0.9 \%, \mathrm{p}=0.023)$ than the well-used Sprague Dawley, while the category Other strains had significantly higher variability $(+20.7 \%$, 0.95 CI: +10.7 to $+30.8 \%$; $\mathrm{p}=0.000$; Figure 2; Table 2).

The only effect of Strain on Mortality rate was that SHR seemed to render lower percentages $(-6.9 \%, 0.95 \mathrm{CI}:-12.8$ to $-0.87 \%$; $\mathrm{p}=0.025$; Figure 2 ; Table 3 ).

The multiple regression analysis addressing hypotheses $1 \mathrm{~A}$ and $2 \mathrm{~A}$ included 469 control groups, while the analysis for hypotheses $1 \mathrm{~B}$ and $2 \mathrm{~B}$ included 351 control groups (Figure 1). These regression formulae had $r^{2}$ of
0.34 and 0.31 , respectively, meaning that they explained $34 \%$ and $31 \%$ of the variation in the outcomes Infarct size coefficient of variation and Mortality rate.

Impact of focal ischemia procedure on infarct size coefficient of variation and mortality: Hypotheses 2A-B

Regarding Infarct size coefficient of variation, all analyzed surgical procedures had positive regression coefficients, indicating higher variability than in the intraluminal filament method, here chosen to be the reference. This trend was significant for the Emboli ( $+14.7 \%$, 0.95 CI: +3.4 to $+26.0 \%$; 
Table 3 Regression formula for hypotheses $1 B$ and 2B

\begin{tabular}{|c|c|c|c|c|c|}
\hline \multicolumn{6}{|c|}{ Regression formula for the effect of Strain and Type of middle cerebral artery occlusion procedure on Mortality rate (hypotheses 1B and 2B) } \\
\hline \multirow{2}{*}{$\begin{array}{l}\text { Variable (reference category) } \\
\text { Constant }\end{array}$} & \multirow{2}{*}{$\begin{array}{c}\text { Variable categories } \\
\text { NA }\end{array}$} & \multirow{2}{*}{$\begin{array}{c}\text { Regression coefficient } \\
17.1\end{array}$} & \multicolumn{2}{|c|}{$\begin{array}{l}0.95 \text { confidence interval } \\
\text { for regression coefficient }\end{array}$} & \multirow{2}{*}{$\begin{array}{r}\text { p-value } \\
0.000\end{array}$} \\
\hline & & & 13.9 & 20.3 & \\
\hline \multirow[t]{4}{*}{ Strain (Sprague Dawley) } & Wistar & 1.0 & -2.4 & 4.4 & 0.551 \\
\hline & SHR & -6.9 & -12.8 & -.87 & 0.025 \\
\hline & WKY & -8.3 & -19.3 & 2.8 & 0.141 \\
\hline & Other Strains & 4.4 & -1.1 & 9.9 & 0.113 \\
\hline \multirow{4}{*}{$\begin{array}{l}\text { Type of middle cerebral artery occlusion } \\
\text { procedure (Intraluminal filament) }\end{array}$} & Direct, mechanical & -10.7 & -15.1 & -6.2 & 0.000 \\
\hline & Embolic & 12.1 & 6.9 & 17.3 & 0.000 \\
\hline & Photothrombotic & -5.6 & -15.3 & 4.2 & 0.262 \\
\hline & Endothelin injection & -9.7 & -16.8 & -2.6 & 0.007 \\
\hline \multirow[t]{4}{*}{ Type of anesthetic (Inhalation anesthetic) } & Chloral Hydrate & 4.1 & 0.17 & 8.1 & 0.041 \\
\hline & Ketamine & 3.2 & -1.1 & 7.4 & 0.144 \\
\hline & Barbiturates and bensodiazepines & 1.1 & -4.6 & 6.8 & 0.710 \\
\hline & Other anesthetic & 3.0 & -1.9 & 8.0 & 0.230 \\
\hline Awakening of rats during occlusion (No) & [Yes] & 9.1 & 3.9 & 14.2 & 0.001 \\
\hline Heart rate monitored (No) & [Yes] & -3.3 & -7.5 & 0.94 & 0.127 \\
\hline Blood glucose concentration analyzed (No) & [Yes] & -2.8 & -6.1 & 0.53 & 0.099 \\
\hline \multirow[t]{3}{*}{ Type of infarct size evaluation (TTC) } & Radiology & 5.4 & -0.11 & 10.9 & 0.055 \\
\hline & Acidic/Basic stain or silver stain histology & -1.2 & -4.7 & 2.4 & 0.526 \\
\hline & Immunohistology & 10.4 & 3.2 & 17.6 & 0.005 \\
\hline \multirow[t]{4}{*}{ Criteria for excluding rats (None) } & $\begin{array}{l}\text { Observed absence of cerebral } \\
\text { blood flow reduction }\end{array}$ & -4.0 & -6.9 & -1.1 & 0.008 \\
\hline & Lack of functional deficit & 0.15 & -3.4 & 3.7 & 0.933 \\
\hline & Too small infarct & 0.22 & -5.1 & 5.6 & 0.935 \\
\hline & Other pathology in animal & -3.4 & -7.1 & 0.40 & 0.079 \\
\hline
\end{tabular}

Variables excluded by statistical software due to too low explanatory value: Sex, Elderly rats, Weight, Intubation, Temperature feedback system, Blood pressure monitored, Blood gases $/ \mathrm{O}_{2}$ saturation analyzed, Blood hemoglobin concentration analyzed, Postoperative antibiotics, Occlusion duration, Time after focal ischemia for evaluation of damage, Edema correction used, Blinding of infarct size determination procedure.

$\mathrm{p}=0.011)$ and Endothelin $(+23.1 \%, 0.95 \mathrm{CI}:+9.3$ to $+36.9 \%$; $\mathrm{p}=0.001$ ) categories (Figure 3, Table 2).

The emboli $(+12.1 \%$, $0.95 \mathrm{CI}:+6.9$ to $+17.3 \%$; $\mathrm{p}=0.000)$ method rendered higher mortality than the intraluminal filament method, while the direct $(-10.7 \%, 0.95 \mathrm{CI}:-15.1$ to $-6.2 \% ; \mathrm{p}=0.000)$ and endothelin $(-9.7 \%, 0.95 \mathrm{CI}:-16.8$ to $-2.6 \% ; \mathrm{p}=0.000)$ methods resulted in lower mortality (Figure 3, Table 3).

Impact of type of filament on infarct size coefficient of variation and mortality: Hypotheses $3 \mathrm{~A}-\mathrm{B}$

In studies in which the intraluminal filament method had been used, silicone coating of the occluding filament substantially and significantly lowered Infarct size coefficient of variation compared to uncoated filaments $(-12.7 \%, 0.95 \mathrm{CI}:-18.3$ to $-7.0 \%$; 0.000$)$. It should also be noted that Poly-L-Lysine had a positive regression coefficient, indicating a slight trend of increased rather than decreased variability in comparison with the reference category (Figure 4, Table 4).

The choice of filament coating had no significant effects on mortality, and regression coefficients were generally small (Figure 4, Table 5).

The multiple regression analyses addressing hypotheses $3 \mathrm{~A}$ and $3 \mathrm{~B}$ included 383 and 265 control groups, respectively, all using the intraluminal filament technique (Figure 1). These regression formulae had $r^{2}$ of 0.40 and 0.27 .

\section{Background data}

In the 502 control groups finally included, the Infarct size coefficient of variation were on average $28.9 \pm 21.3 \%$, with a 
Table 4 Regression formula for hypothesis 3A

\begin{tabular}{|c|c|c|c|c|c|}
\hline \multicolumn{6}{|c|}{ Regression formula for the effect of Occluding filament type on Infarct size coefficient of variation (hypothesis 3A) } \\
\hline \multirow{2}{*}{$\begin{array}{l}\text { Variable (reference category) } \\
\text { Constant }\end{array}$} & \multirow{2}{*}{$\begin{array}{c}\text { Variable categories } \\
\text { NA }\end{array}$} & \multirow{2}{*}{$\begin{array}{c}\text { Regression coefficient } \\
49.1\end{array}$} & \multicolumn{2}{|c|}{$\begin{array}{l}0.95 \text { confidence interval for } \\
\text { regression coefficient }\end{array}$} & \multirow{2}{*}{$\begin{array}{r}\mathbf{p} \text {-value } \\
0.000\end{array}$} \\
\hline & & & 38.7 & 59.4 & \\
\hline \multirow[t]{3}{*}{ Occluding filament type (Uncoated) } & Silicon coated & -12.7 & -18.3 & -7.0 & 0.000 \\
\hline & Poly-L-Lysine coated & 3.1 & -4.8 & 11.0 & 0.444 \\
\hline & Other coatings & 3.1 & -5.0 & 11.3 & 0.451 \\
\hline \multirow[t]{4}{*}{ Strain (Sprague Dawley) } & Wistar & -2.1 & -8.3 & 4.1 & 0.507 \\
\hline & $S H R$ & -3.0 & -17.2 & 11.2 & 0.679 \\
\hline & $W K Y$ & 16.1 & -5.6 & 37.8 & 0.146 \\
\hline & Other Strains & 25.9 & 11.0 & 40.7 & 0.001 \\
\hline \multirow[t]{3}{*}{ Sex (Male) } & Female & 3.3 & -17.0 & 23.7 & 0.747 \\
\hline & Ovx female & 12.1 & -8.5 & 32.6 & 0.248 \\
\hline & Mix or not specified & -5.0 & -15.1 & 5.2 & 0.335 \\
\hline Elderly rats & [Yes] & -17.8 & -38.4 & 2.9 & 0.091 \\
\hline \multirow[t]{4}{*}{ Type of anesthetic (inhalation anesthetic) } & Chloral Hydrate & -12.0 & -18.7 & -5.4 & 0.000 \\
\hline & Ketamine & 4.5 & -4.3 & 13.2 & 0.315 \\
\hline & Barbiturates and bensodiazepines & -12.4 & -24.8 & 0.00 & 0.050 \\
\hline & Other anesthetic & -14.2 & -24.1 & -4.4 & 0.005 \\
\hline Awakening of rats during occlusion (No) & [Yes] & 10.4 & 2.1 & 18.6 & 0.014 \\
\hline Temperature feedback system (No) & [Yes] & -7.6 & -14.1 & -1.2 & 0.021 \\
\hline Blood pressure monitored (No) & [Yes] & -12.0 & -21.4 & -2.6 & 0.013 \\
\hline Heart rate monitored (No) & [Yes] & 14.9 & 5.4 & 24.4 & 0.002 \\
\hline Blood gases $/ \mathrm{O}_{2}$ saturation analyzed (No) & [Yes] & 11.5 & 1.8 & 21.1 & 0.021 \\
\hline $\begin{array}{l}\text { Blood hemoglobin concentration } \\
\text { analyzed (No) }\end{array}$ & [Yes] & 10.7 & 1.5 & 19.9 & 0.023 \\
\hline \multirow[t]{2}{*}{ Occlusion duration (Short transient) } & Long transient & -3.3 & -9.3 & 2.8 & 0.288 \\
\hline & Permanent & -21.4 & -30.1 & -12.8 & 0.000 \\
\hline $\begin{array}{l}\text { Time after focal ischemia for evaluation } \\
\text { of damage }\end{array}$ & [Continuous; Hours] & 0.000036 & -0.000013 & 0.000087 & 0.157 \\
\hline $\begin{array}{l}\text { Blinding of infarct size determination } \\
\text { procedure (No) }\end{array}$ & [Yes] & -3.8 & -9.9 & 2.2 & 0.211 \\
\hline \multirow[t]{4}{*}{ Criteria for excluding rats (None) } & $\begin{array}{c}\text { Observed absence of cerebral blood flow } \\
\text { reduction }\end{array}$ & -7.4 & -13.1 & -1.7 & 0.011 \\
\hline & Lack of functional deficit & -5.6 & -12.0 & 0.7 & 0.083 \\
\hline & Too small infarct & 7.6 & -4.5 & 19.6 & 0.219 \\
\hline & Other pathology in animal & 16.2 & 8.7 & 23.6 & 0.000 \\
\hline
\end{tabular}

Variables excluded by statistical software due to too low explanatory value: Weight, Intubation, Postoperative antibiotics, Blood glucose concentration analyzed, Type of infarct size evaluation, Edema correction used.

range from 1.7 to $148 \%$. Mortality rate, the other outcome variable, averaged $15.1 \pm 13.5 \%$, ranging from 0 to $60.4 \%$.

The average number of animals in the 502 control groups, which was used for weighing the studies' impact in the analyses, was 9.0 \pm 7.7 , with a range from 3 to 145 . Mean rat body weight in the included studies was $294.9 \pm$ $61.0 \mathrm{~g}$, ranging from group means of 190 to $779 \mathrm{~g}$. Cerebral damage was evaluated on average $165.5 \pm 506.3$ hours after ischemic insult, but this data was heavily skewed, with a median of 24 hours. The exclusion rate (due to other reasons than mortality) averaged $8.9 \pm 9.8 \%$ in the few studies in which this information was available. Frequencies of the different classifications in the registered categorical variables are presented in Figure 5.

\section{Discussion}

The most important findings in the current hypothesisdriven meta-analysis was that the Wistar strain and 
Table 5 Regression formula for hypotheses 3B

\begin{tabular}{|c|c|c|c|c|c|}
\hline \multicolumn{6}{|c|}{ Regression formula for the effect of Occluding filament type on Mortality rate (hypothesis 3B) } \\
\hline \multirow{2}{*}{$\begin{array}{l}\text { Variable (reference category) } \\
\text { Constant }\end{array}$} & \multirow{2}{*}{$\begin{array}{c}\text { Variable categories } \\
\text { NA }\end{array}$} & \multirow{2}{*}{$\begin{array}{c}\text { Regression coefficient } \\
16.8\end{array}$} & \multicolumn{2}{|c|}{$\begin{array}{l}0.95 \text { confidence interval } \\
\text { for regression coefficient }\end{array}$} & \multirow{2}{*}{$\begin{array}{r}\text { p-value } \\
0.000\end{array}$} \\
\hline & & & 13.2 & 20.4 & \\
\hline \multirow[t]{3}{*}{ Occluding filament type (Uncoated) } & Silicon coated & -1.2 & -4.7 & 2.4 & 0.516 \\
\hline & Poly-L-Lysine coated & 3.0 & -1.3 & 7.4 & 0.171 \\
\hline & Other coatings & -3.6 & -9.0 & 1.8 & 0.188 \\
\hline \multirow[t]{4}{*}{ Type of anesthetic (Inhalation anesthetic) } & Chloral Hydrate & 5.0 & 0.57 & 9.4 & 0.027 \\
\hline & Ketamine & 3.1 & -1.6 & 7.8 & 0.198 \\
\hline & Barbiturates and bensodiazepines & 6.6 & -0.91 & 14.1 & 0.085 \\
\hline & Other anesthetic & 5.6 & -0.04 & 11.2 & 0.052 \\
\hline Awakening of rats during occlusion (No) & [Yes] & 9.7 & 4.5 & 14.8 & 0.000 \\
\hline Heart rate monitoring (No) & [Yes] & -6.5 & -10.8 & -2.2 & 0.003 \\
\hline \multirow[t]{3}{*}{ Type of infarct size evaluation (TTC) } & Radiology & 13.3 & 6.5 & 20.1 & 0.000 \\
\hline & Acidic/Basic stain or silver stain histology & -1.2 & -5.2 & 2.9 & 0.576 \\
\hline & Immunohistology & 10.8 & 1.6 & 20.0 & 0.022 \\
\hline \multirow[t]{4}{*}{ Criteria for excluding rats (None) } & $\begin{array}{c}\text { Observed absence of cerebral blood flow } \\
\text { reduction }\end{array}$ & -5.5 & -8.6 & -2.4 & 0.001 \\
\hline & Lack of functional deficit & .39 & -3.5 & 4.2 & 0.843 \\
\hline & Too small infarct & -7.4 & -14.2 & -.56 & 0.034 \\
\hline & Other pathology in animal & -1.2 & -5.3 & 2.9 & 0.577 \\
\hline
\end{tabular}

Variables excluded by statistical software due to too low explanatory value: Strain, Sex, Elderly rats, Weight, Intubation, Temperature feedback system, Blood pressure monitoring, Blood gases $/ \mathrm{O}_{2}$ saturation analyzed, Blood hemoglobin concentration analyzed, Blood glucose concentration analyzed, Postoperative antibiotics, Occlusion duration, Time after focal ischemia for evaluation of damage, Edema correction used, Blinding of infarct size determination procedure.

intraluminal filament procedure using a silicone coated filament resulted in smallest infarct size variability. The direct and endothelin methods rendered the lowest mortality rates, while the emboli method increased mortality when compared to the intraluminal filament method. A number of interesting observations regarding the control variables were also made, such as the significant impact of the exclusion criterion Observed absence of cerebral blood flow reduction on variability (Table 2) and the effect of awakening the rats during occlusion on mortality (Table 3). However, since these accidental findings were not part of the original hypothesis, we refrain from drawing any conclusions about them, and refer to Tables 2, 3, 4, 5 for the interested reader.

The high infarct size variability in rodent focal ischemic models is a problem that burdens the entire experimental stroke field, and has been commented in several reviews $[2,362]$. The problem with high outcome variability is that a higher number of animals is needed to
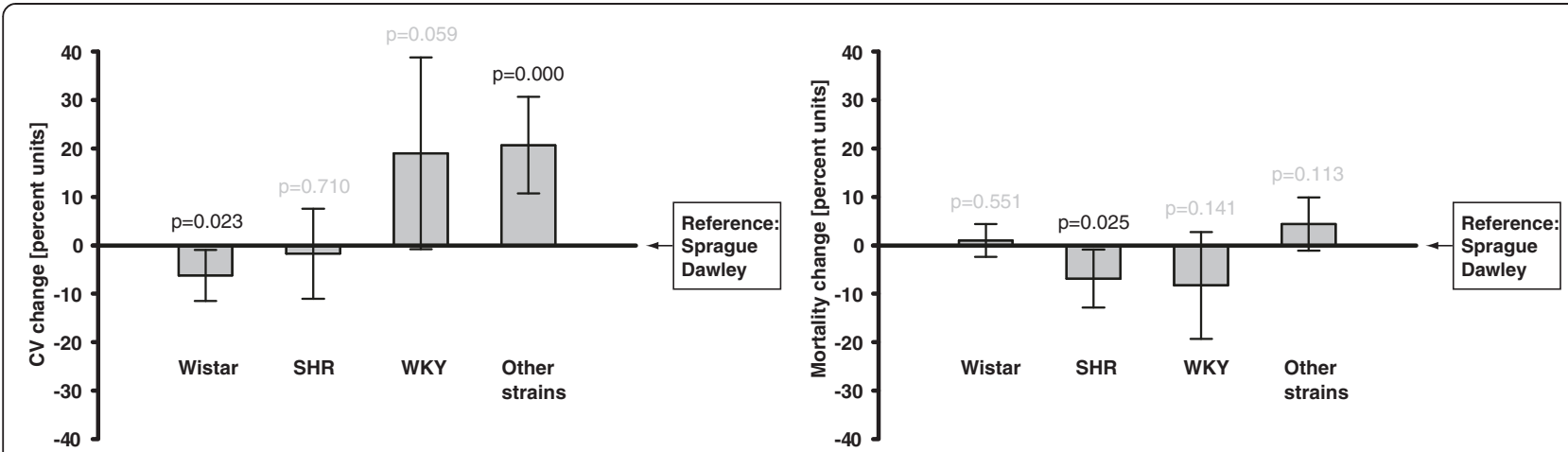

Figure $\mathbf{2}$ The choice of strain significantly affected the Infarct size coefficient of variation, so that the Wistar rendered lower variability than Sprague Dawley, which was chosen as the reference category. The Other strains category increased variability in comparison to Sprague Dawley. Regarding mortality rate, the effects of animal strain was limited to a slight decrease from using $S H R$. N $=469$ and 351 , respectively, in the two analyses/graphs. The bars represent 0.95 confidence intervals. 

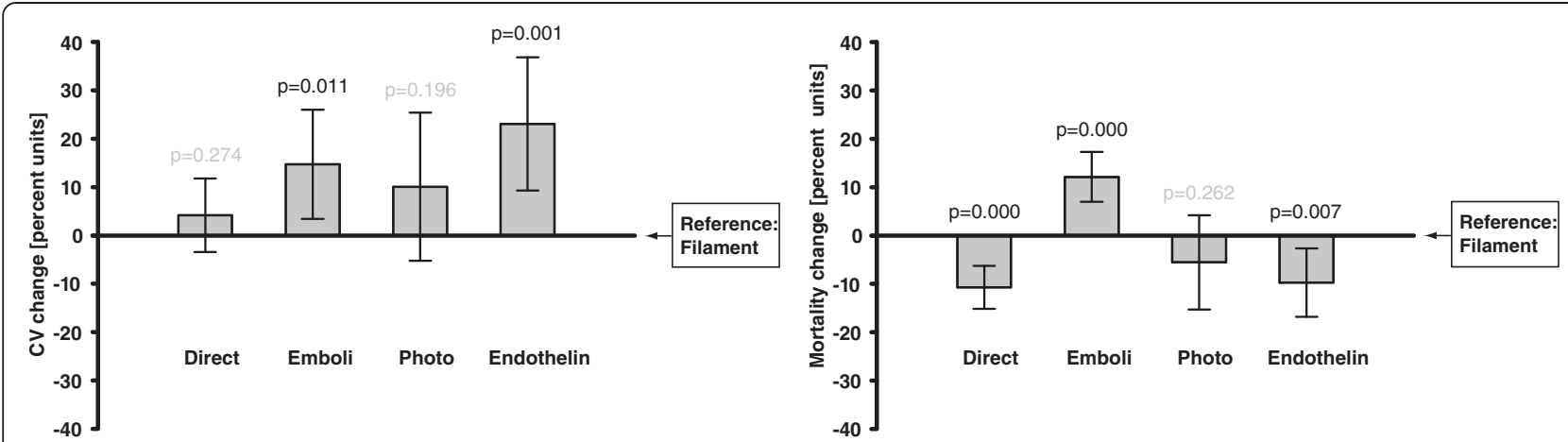

Figure 3 Concerning Infarct size coefficient of variation, the general trend was that the intraluminal filament procedure, here chosen to be the reference category, resulted in lower percentages than did the other methods. The emboli and endothelin injection methods rendered significantly higher variability. Mortality rate was clearly influenced by choice of induction procedure, with higher percentages in the emboli studies, while the direct and endothelin procedures had decreased numbers of deaths in comparison to the intraluminal filament method. $N=469$ and 351 , respectively, in the two analyses/graphs. The bars represent 0.95 confidence intervals.

get an adequate statistical power, which is problematic from both an ethical and economical point of view. The pressure from ethical boards on the researcher to minimize the number of animals used may be the main reason that the power of stroke experiments is often low. In the current meta-analysis, the average infarct size coefficient of variation was $28.9 \%$, while the average number of animals included in the control groups were 9.0. If we assume that the animals in the included studies often are equally distributed between the treatment groups and control groups, these numbers can provide an estimate of the average statistical power in the studies. Given the abovementioned numbers and an alpha of 0.05 , the chance of detecting a $20 \%$ difference between the groups would be merely $54.6 \%$ (if non-parametric tests are used instead or if more than two groups are included in the comparison, the power would be even lower). Under these circumstances, a negative result is marginally more interesting that tossing a coin. The use of low power designs risks serious publication bias which also makes meta-analyses of experimental stroke studies difficult to interpret properly, since there is probably an unknown number of unpublished studies that cannot be weighed in. In addition to using means to decrease variability, it is of fundamental importance to use a sufficient number of animals/replicates to render an acceptably high power.

Mortality can be another confounding factor in experimental stroke research, at least if it is not reported in the article. With parametric statistical methods, incorporating mortality in for example the infarct size calculations is not uncomplicated from a statistical point of view, which is probably why the mortality is often simply not mentioned. Non-parametric models may offer an alternative approach [363], but irrespective of how the main outcome is statistically assessed, the importance of reporting mortality and other exclusion criteria cannot be over-emphasized. For example, if mortality rate is omitted, a substance that kills all rats with large infarcts may seem to decrease infarct sizes, since only the animals with small infarcts will survive in the treatment group. Unfortunately, mortality rate is usually not
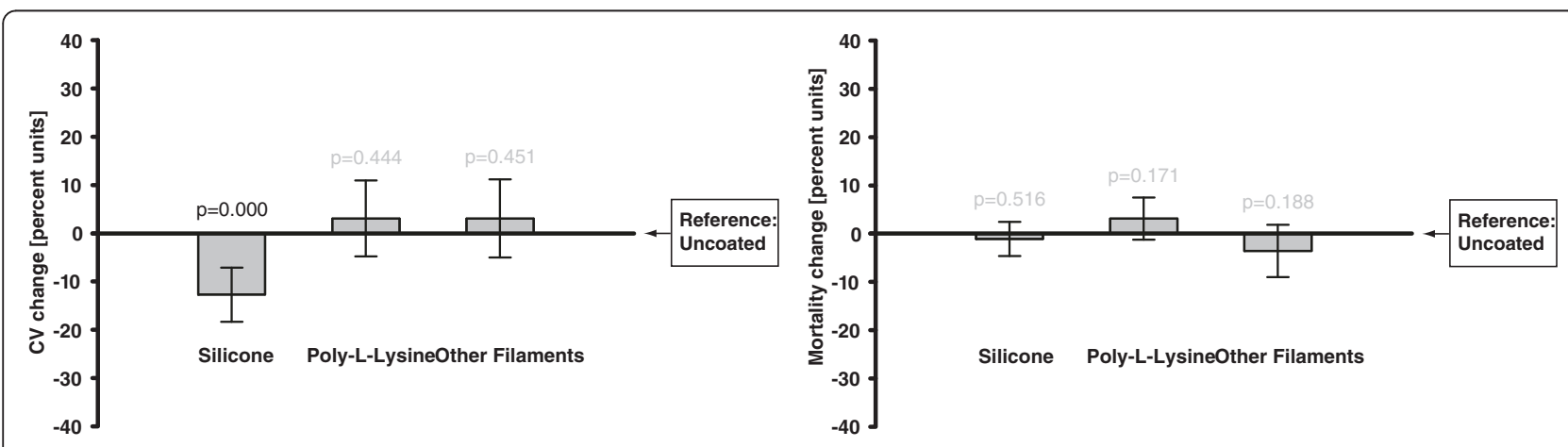

Figure 4 Silicone coated filaments rendered lower infarct size coefficient of variation than the uncoated filaments. Poly-L-Lysine coated and other filaments resulted in infarct size coefficients of variation comparable to the uncoated counterparts. No effect on Mortality rate from the choice of intraluminal filament type was seen. $N=383$ and 265, respectively, in the two analyses/graphs. The bars represent 0.95 confidence intervals. 
reported in experimental stroke studies. In fact, for only $35.3 \%$ of the included control groups an account of unintended deaths was provided; and this was the most frequently requested item in our e-mail correspondence.

A few previous studies have assessed the influence of the rat strain on experimental stroke outcomes, however with conflicting results. Spontaneously hypertensive rats (SHR) have, probably because of the implications of hypertension in stroke pathophysiology, attracted some attention. Since this strain often sustains larger infarcts [364], the infarct size coefficient of variation has in a few studies been shown to be relatively low $[8,365,366]$. Others have argued that the use of another inbred strain - Fischer-344 rats - give the most consistent results [7,367,368], however this type may because of its variable vascular anatomy be unsuitable for the well-used intraluminal filament model [369]. Long Evans rats have also been proponed as a good model animal, because of the relatively consistent decrease in cerebral blood flow after intraluminal filament MCAo [370]. Many other studies have investigated differences between rat strains, however not focusing on variability, but rather on infarct sizes per se [371-373]. Except for the study emphasizing the unsuitability of Fischer-344 for intraluminal filament MCAo [369], we are only aware of one study aiming to compare mortality between strains. In this study, an intraluminal filament model rendered higher mortality in Fischer-344 rats than in Wistar and Sprague-Dawley rats [7]. It is not easy to summarize the conclusions in the existing literature, since the mentioned experiments have been performed under such different circumstances, but it seems that SHR might be attractive because of their low variability. In the current metaanalysis, there was a slight trend towards lower variability in the SHR strain compared to the reference category Sprague-Dawley, which however was far from reaching statistical significance. Regarding Long Evans and Fischer344 , these strains were used too rarely to be analyzed separately. As abovementioned, the strain that we found to render the lowest variability was the relatively well-used Wistar strain.

Very few studies have compared different methods of inducing focal cerebral ischemia. This is perhaps not surprising given that the effort of introducing an entirely new MCAo method in a laboratory is large enough to make many researchers reluctant to switch once a technique has been mastered. This lack of relevant studies underscores the importance of a meta-analysis as the current one. However, in a study by Gerriets et al. [10], an embolization technique was compared to an intraluminal filament procedure. The take-home message from that article was that even though infarct variability tended to be higher from the emboli method, as corroborated by the current study, it did not affect body temperature to the same extent as the filament method did. In another article, the use of microsurgical direct occlusion was advocated over the intraluminal filament method because the latter was thought to not only compromise blood flow to the MCA territory, but rather a larger part of the ICA territory [374].

Different types of filaments for the intraluminal method are much easier to compare, and have been assessed in several studies. Most of these studies have argued that silicone coated rather than uncoated or poly-L-lysine coated filaments should be used, because of a more consistent blood flow reduction [375], lower incidence of sub-arachnoid hemorrhage [14,376], higher success rate [376-378], lower mortality [377] and lower variability [368,376], even if arguments based on low variability also have been used to encourage the use of poly-L-lysine coating [379]. In the current analysis, it was found that silicone coated filaments are superior in terms of reducing infarct size variability, while no effects on mortality were found. Another study compared different brands of blunted nylon filaments, and found Ethilon to be superior to Nitcho [380].

\section{Strengths and weaknesses}

The main strength of the current study is that it, based on hundreds of published studies, provides a composite understanding of how different methodological factors interact to affect outcome variability and mortality. However, since this method-investigating meta-analytical approach is relatively novel, we consider it important to highlight and discuss some aspects of the design:

- A multiple regression analysis assumes that the variables are linearly related, which evidently is not always true. For example, the effect of average body weight on variability could theoretically be U-shaped, with higher variability in young, not fully developed, rats and very old animals, than in adult animals. This is an inherent drawback, but multiple regression analysis still seemed the most attractive statistical method for the current purpose.

- There is a problem in investigating coefficients of variation in published studies, and weighing the impact of the included control groups by number of animals, since important sources of bias come into play. Researchers that know that their model render large variability will compensate by including more animals, thus giving more weight in the metaanalysis to studies with larger variability. We however believe that weighing the analysis by number of animals is the fairest alternative. Another problem is publication bias, since the studies rendering the largest coefficients of variation probably to large part remain unpublished, and cannot be assessed.

- Even if this meta-analysis controls for many confounders by its broad approach, there is 
complexity and heterogeneity in the underlying experiments that is far beyond our reach. For example, the impact of different rat vendors [381], the skill of the surgeon and the suitability of using specific rat strains for certain surgical procedures are not accounted for. For mathematical reasons, categories have also, as stated in the Materials and Methods section, been reduced to larger categories, meaning that differences within categories may be lost. There are for example numerous variations within the different MCAo techniques, and it is likely that the best embolization procedure renders a lower variability than the worst intraluminal filament paradigm, even if the last-mentioned method proved superior on a general level.

- The meta-analysis includes 502 control groups from only 346 published reports, meaning that several studies described more than one control group. We have in the statistical analysis regarded control groups from the same study as independent, which is not statistically stringent. However, if categories had been created for all separate studies, the entire analysis would have been impossible to perform, and thus this imperfection is an inevitable problem with the chosen approach.

\section{Conclusions}

The choice of methodological parameters, such as rat strain and infarct surgical procedures, is of utmost importance for consistent and reliable results. As found in the meta-analysis, the effect sizes were large, with many parameters by themselves increasing or decreasing variability and mortality with more than $10 \%$ (in absolute terms).

Finally, it deserves to be emphasized that this analysis does not encompass all perspectives on the suitability of focal stroke models. Even if infarct size coefficient of variation and mortality are important components, other aspects, not least similarity of the model to the clinical situation, emphasizing the importance of the embolic model [382], must be taken into consideration when planning experiments.

\footnotetext{
Abbreviations

MCAo: Middle cerebral artery occlusion; MCA: Middle cerebral artery; SHR: Spontaneously hypertensive rat; WKY: Wistar Kyoto rats; Ovx: Ovariectomized; CV: Coefficient of variation, calculated as [standard deviation/average]; Cl: Confidence interval; EEG: Electroencephalography; Hb: Hemoglobin.
}

\section{Competing interests}

The authors declared that they have no competing interests.

\section{Authors' contributions}

JOS contributed to designing the study, extracted data, performed the outcome analyses and drafted the manuscript. El contributed to designing the study, extracted data and revised the manuscript. AT and ET contributed to designing the study and revised the manuscript. All authors read and approved the final manuscript version before submission.

\section{Acknowledgements}

First and foremost, we would like to express our sincere gratitude towards our fellow researchers who embodied scientific good-will by generously sharing unpublished details concerning their experiments. We also gratefully acknowledge the expert advice of statistician Karl Wahlin PhD. This study was supported by the County Council of Östergötland, Sweden.

\section{Author details}

'Department of Clinical and Experimental Medicine, Clinical Chemistry, Faculty of Health Sciences, Linköping University, County Council of Östergötland, Linköping, Sweden. ${ }^{2}$ Department of Clinical and Experimental Medicine, Neurosurgery, Faculty of Health Sciences, Linköping University, County Council of Östergötland, Linköping, Sweden.

Received: 29 November 2012 Accepted: 22 March 2013

Published: 1 April 2013

\section{References}

1. O'Collins VE, Macleod MR, Donnan GA, Horky LL, van der Worp BH, Howells DW: 1,026 experimental treatments in acute stroke. Ann Neurol 2006, 59(3):467-477.

2. Macleod MR, Fisher M, O'Collins V, Sena ES, Dirnagl U, Bath PM, Buchan A, van der Worp HB, Traystman RJ, Minematsu K, et al: Reprint: Good laboratory practice: preventing introduction of bias at the bench. J Cereb Blood Flow Metab 2009, 29(2):221-223.

3. van der Worp HB, de Haan P, Morrema E, Kalkman CJ: Methodological quality of animal studies on neuroprotection in focal cerebral ischaemia. J Neurol 2005, 252(9):1108-1114.

4. Philip M, Benatar M, Fisher M, Savitz SI: Methodological quality of animal studies of neuroprotective agents currently in phase II/III acute ischemic stroke trials. Stroke 2009, 40(2):577-581.

5. Longa EZ, Weinstein PR, Carlson S, Cummins R: Reversible middle cerebral artery occlusion without craniectomy in rats. Stroke 1989, 20(1):84-91.

6. Belayev L, Alonso OF, Busto R, Zhao W, Ginsberg MD: Middle cerebral artery occlusion in the rat by intraluminal suture. Neurological and pathological evaluation of an improved model. Stroke 1996, 27(9):1616-1622. discussion 1623.

7. Aspey BS, Taylor FL, Terruli M, Harrison MJ: Temporary middle cerebral artery occlusion in the rat: consistent protocol for a model of stroke and reperfusion. Neuropathol Appl Neurobiol 2000, 26(3):232-242.

8. Barone FC, Price WJ, White RF, Willette RN, Feuerstein GZ: Genetic hypertension and increased susceptibility to cerebral ischemia. Neurosci Biobehav Rev 1992, 16(2):219-233.

9. Menzies SA, Hoff JT, Betz AL: Middle cerebral artery occlusion in rats: a neurological and pathological evaluation of a reproducible model. Neurosurgery 1992, 31(1):100-106. discussion 106-107.

10. Gerriets T, Li F, Silva MD, Meng X, Brevard M, Sotak CH, Fisher M: The macrosphere model: evaluation of a new stroke model for permanent middle cerebral artery occlusion in rats. J Neurosci Meth 2003, 122(2):201-211.

11. Boyko M, Zlotnik A, Gruenbaum BF, Gruenbaum SE, Ohayon S, Goldsmith T, Kotz R, Leibowitz A, Sheiner E, Shapira Y, et al: An experimental model of focal ischemia using an internal carotid artery approach. $J$ Neurosci Meth 2010, 193(2):246-253.

12. Chen ST, Hsu CY, Hogan EL, Maricq H, Balentine JD: A model of focal ischemic stroke in the rat: reproducible extensive cortical infarction. Stroke 1986, 17(4):738-743.

13. Dittmar M, Spruss T, Schuierer G, Horn M: External carotid artery territory ischemia impairs outcome in the endovascular filament model of middle cerebral artery occlusion in rats. Stroke 2003, 34(9):2252-2257.

14. Schmid-Elsaesser R, Zausinger S, Hungerhuber E, Baethmann A, Reulen HJ: A critical reevaluation of the intraluminal thread model of focal cerebral ischemia: evidence of inadvertent premature reperfusion and subarachnoid hemorrhage in rats by laser-Doppler flowmetry. Stroke 1998, 29(10):2162-2170.

15. Sheng H, Spasojevic I, Tse HM, Jung JY, Hong J, Zhang Z, Piganelli JD, Batinic-Haberle I, Warner DS: Neuroprotective efficacy from a lipophilic redox-modulating $\mathrm{Mn}$ (III) N-Hexylpyridylporphyrin, MnTnHex-2-PyP: 
rodent models of ischemic stroke and subarachnoid hemorrhage. J Pharmacol Exp Ther 2011, 338(3):906-916.

16. Ye R, Kong X, Yang Q, Zhang Y, Han J, Li P, Xiong L, Zhao G: Ginsenoside rd in experimental stroke: superior neuroprotective efficacy with a wide therapeutic window. Neurotherapeutics 2011, 8(3):515-525.

17. Sun J, Li Y, Fang W, Mao L: Therapeutic time window for treatment of focal cerebral ischemia reperfusion injury with $X Q-1 \mathrm{~h}$ in rats. Eur J Pharmacol 2011, 666(1-3):105-110

18. Rau TF, Kothiwal A, Zhang L, Ulatowski S, Jacobson S, Brooks DM, CardozoPelaez F, Chopp M, Poulsen DJ: Low dose methamphetamine mediates neuroprotection through a PI3K-AKT pathway. Neuropharmacology 2011, 61(4):677-686

19. Maheshwari A, Badgujar L, Phukan B, Bodhankar SL, Thakurdesai P: Protective effect of Etoricoxib against middle cerebral artery occlusion induced transient focal cerebral ischemia in rats. Eur J Pharmacol 2011, 667(1-3):230-237.

20. Ceulemans AG, Zgavc T, Kooijman R, Hachimi-Idrissi S, Sarre S, Michotte Y: Mild hypothermia causes differential, time-dependent changes in cytokine expression and gliosis following endothelin-1-induced transient focal cerebral ischemia. J Neuroinflammation 2011, 8:60.

21. Sun B, Chen L, Wei X, Xiang Y, Liu X, Zhang X: The Akt/GSK-3beta pathway mediates flurbiprofen-induced neuroprotection against focal cerebral ischemia/reperfusion injury in rats. Biochem Biophys Res Commun 2011 409(4):808-813.

22. Suda S, Shimazaki K, Ueda M, Inaba T, Kamiya N, Katsura K, Katayama Y: Combination therapy with bone marrow stromal cells and FK506 enhanced amelioration of ischemic brain damage in rats. Life Sci 2011, 89(1-2):50-56

23. Yang J, Song TB, Zhao ZH, Qiu SD, Hu XD, Chang L: Vasoactive intestinal peptide protects against ischemic brain damage induced by focal cerebral ischemia in rats. Brain Res 2011, 1398:94-101.

24. Andres RH, Horie N, Slikker W, Keren-Gill H, Zhan K, Sun G, Manley NC, Pereira MP, Sheikh LA, McMillan EL, et al: Human neural stem cells enhance structural plasticity and axonal transport in the ischaemic brain. Brain 2011, 134(Pt 6):1777-1789.

25. Ma S, Yin H, Chen L, Liu H, Zhao M, Zhang X: Neuroprotective effect of ginkgolide $\mathrm{K}$ against acute ischemic stroke on middle cerebral ischemia occlusion in rats. J Nat Med 2012, 66(1):25-31.

26. Lammer AB, Beck A, Grummich B, Forschler A, Krugel T, Kahn T, Schneider $D$, Illes $P$, Franke $H$, Krugel U: The P2 receptor antagonist PPADS supports recovery from experimental stroke in vivo. PLOS One 2011, 6(5):e19983.

27. Kaur J, Tuor UI, Zhao Z, Barber PA: Quantitative MRI reveals the elderly ischemic brain is susceptible to increased early blood-brain barrier permeability following tissue plasminogen activator related to claudin 5 and occludin disassembly. J Cereb Blood Flow Metab 2011, 31(9):1874-1885.

28. McLeod DD, Parsons MW, Levi CR, Beautement S, Buxton D, Roworth B, Spratt NJ: Establishing a rodent stroke perfusion computed tomography model. Int J Stroke 2011, 6(4):284-289.

29. Chang HC, Yang YR, Wang PS, Kuo CH, Wang RY: Insulin-like growth factor I signaling for brain recovery and exercise ability in brain ischemic rats. Med Sci Sports Exerc 2011, 43(12):2274-2280.

30. Nair SM, Rahman RM, Clarkson AN, Sutherland BA, Taurin S, Sammut IA, Appleton I: Melatonin treatment following stroke induction modulates Larginine metabolism. J Pineal Res 2011, 51(3):313-323.

31. Koh PO: Nicotinamide attenuates the ischemic brain injury-induced decrease of Akt activation and Bad phosphorylation. Neurosci Lett 2011, 498(2):105-109.

32. Boyko M, Ohayon S, Goldsmith T, Douvdevani A, Gruenbaum BF, Melamed I, Knyazer B, Shapira Y, Teichberg VI, Elir A, et al: Cell-free DNA-a marker to predict ischemic brain damage in a rat stroke experimental model. J Neurosurg Anesthesiol 2011, 23(3):222-228.

33. Wu WN, Wu PF, Chen XL, Zhang Z, Gu J, Yang YJ, Xiong QJ, Ni L, Wang F, Chen JG: Sinomenine protects against ischaemic brain injury: involvement of co-inhibition of acid-sensing ion channel 1a and L-type calcium channels. Br J Pharmacol 2011, 164(5):1445-1459.

34. Song M, Kim YJ, Kim YH, Roh J, Kim SU, Yoon BW: Effects of duplicate administration of human neural stem cell after focal cerebral ischemia in the rat. Int J Neurosci 2011, 121(8):457-461.
35. Lin YC, Ko TL, Shih YH, Lin MY, Fu TW, Hsiao HS, Hsu JY, Fu YS: Human umbilical mesenchymal stem cells promote recovery after ischemic stroke. Stroke 2011, 42(7):2045-2053.

36. Yamato M, Shiba T, Ide T, Honda Y, Yamada K, Tsutsui H: Nifedipine treatment reduces brain damage after transient focal ischemia, possibly through its antioxidative effects. Hypertens Res 2011, 34(7):840-845.

37. Robertson CA, McCabe C, Gallagher L, Lopez-Gonzalez Mdel R, Holmes WM, Condon B, Muir KW, Santosh C, Macrae IM: Stroke penumbra defined by an MRI-based oxygen challenge technique: 1. Validation using [14C]2deoxyglucose autoradiography. J Cereb Blood Flow Metab 2011, 31(8):1778-1787.

38. Lipsanen A, Hiltunen M, Jolkkonen J: Chronic ibuprofen treatment does not affect the secondary pathology in the thalamus or improve behavioral outcome in middle cerebral artery occlusion rats. Pharmacol Biochem Behav 2011, 99(3):468-474.

39. Weng H, Shen C, Hirokawa G, Ji X, Takahashi R, Shimada K, Kishimoto C, Iwai N: Plasma miR-124 as a biomarker for cerebral infarction. Biomed Res 2011, 32(2):135-141.

40. Pires PW, Rogers CT, McClain JL, Garver HS, Fink GD, Dorrance AM: Doxycycline, a matrix metalloprotease inhibitor, reduces vascular remodeling and damage after cerebral ischemia in stroke-prone spontaneously hypertensive rats. Am J Physiol Heart Circ Physiol 2011 301(1):H87-H97.

41. Chen C, Cheng Y, Chen J: Transfection of Noggin in bone marrow stromal cells (BMSCs) enhances BMSC-induced functional outcome after stroke in rats. J Neurosci Res 2011, 89(8):1194-1202

42. Pan $Y$, Zhang $H$, Acharya AB, Cruz-Flores S, Panneton WM: The effect of heliox treatment in a rat model of focal transient cerebral ischemia. Neurosci Lett 2011, 497(2):144-147.

43. Zhang X, Deguchi S, Deguchi K, Ohta Y, Yamashita T, Shang J, Tian F, Liu N, Liu W, Ikeda Y, et al: Amlodipine and atorvastatin exert protective and additive effects via antiapoptotic and antiautophagic mechanisms after transient middle cerebral artery occlusion in Zucker metabolic syndrome rats. J Neurosci Res 2011, 89(8):1228-1234.

44. Shimada K, Kitazato KT, Kinouchi T, Yagi K, Tada Y, Satomi J, Kageji T, Nagahiro S: Activation of estrogen receptor-alpha and of angiotensinconverting enzyme 2 suppresses ischemic brain damage in oophorectomized rats. Hypertension 2011, 57(6):1161-1166

45. Wang RY, Chang HC, Chen CH, Tsai YW, Yang YR: Effects of hyperbaric oxygenation on oxidative stress in acute transient focal cerebral ischemic rats. Eur J Appl Physiol 2012, 112(1):215-221.

46. Li M, Zhang X, Cui L, Yang R, Wang L, Liu L, Du W: The neuroprotection of oxymatrine in cerebral ischemia/reperfusion is related to nuclear factor erythroid 2-related factor 2 (nrf2)-mediated antioxidant response: role of nrf2 and hemeoxygenase-1 expression. Biol Pharm Bull 2011, 34(5):595-601.

47. Han Q, Li B, Feng H, Xiao Z, Chen B, Zhao Y, Huang J, Dai J: The promotion of cerebral ischemia recovery in rats by laminin-binding BDNF. Biomaterials 2011, 32(22):5077-5085

48. Yang ZZ, Li J, Li SX, Feng W, Wang H: Effect of ginkgolide B on striatal extracellular amino acids in middle cerebral artery occluded rats. J Ethnopharmacol 2011, 136(1):117-122.

49. Lei C, Deng J, Wang B, Cheng D, Yang Q, Dong H, Xiong L: Reactive oxygen species scavenger inhibits STAT3 activation after transient focal cerebral ischemia-reperfusion injury in rats. Anesth Analg 2011, 113(1):153-159.

50. van Meer MP, van der Marel K, van der Sprenkel JW, Dijkhuizen RM: MRI of bilateral sensorimotor network activation in response to direct intracortical stimulation in rats after unilateral stroke. $J$ Cereb Blood Flow Metab 2011, 31(7):1583-1587.

51. Takeda Y, Zhao L, Jacewicz M, Pulsinelli WA, Nowak TS Jr: Metabolic and perfusion responses to recurrent peri-infarct depolarization during focal ischemia in the Spontaneously Hypertensive Rat: dominant contribution of sporadic CBF decrements to infarct expansion. J Cereb Blood Flow Metab 2011, 31(9):1863-1873.

52. Dejda A, Seaborn T, Bourgault S, Touzani O, Fournier A, Vaudry H, Vaudry D: PACAP and a novel stable analog protect rat brain from ischemia: Insight into the mechanisms of action. Peptides 2011, 32(6):1207-1216.

53. Mariucci G, Taha E, Tantucci M, Spaccatini C, Tozzi A, Ambrosini MV: Intravenous administration of pravastatin immediately after middle cerebral artery occlusion reduces cerebral oedema in spontaneously hypertensive rats. Eur J Pharmacol 2011, 660(2-3):381-386. 
54. Zhang L, Li Y, Zhang C, Chopp M, Gosiewska A, Hong K: Delayed administration of human umbilical tissue-derived cells improved neurological functional recovery in a rodent model of focal ischemia. Stroke 2011, 42(5):1437-1444.

55. Choi Y, Kim SK, Choi IY, Ju C, Nam KW, Hwang S, Kim BW, Yoon MJ, Won $\mathrm{MH}$, Park YK, et al: Amelioration of cerebral infarction and improvement of neurological deficit by a Korean herbal medicine, modified Bo-YangHwan-O-Tang. J Pharm Pharmacol 2011, 63(5):695-706.

56. Kuboyama K, Harada H, Tozaki-Saitoh H, Tsuda M, Ushijima K, Inoue K: Astrocytic $\mathrm{P} 2 \mathrm{Y}(1)$ receptor is involved in the regulation of cytokine/ chemokine transcription and cerebral damage in a rat model of cerebral ischemia. J Cereb Blood Flow Metab 2011, 31(9):1930-1941.

57. Titova E, Ostrowski RP, Adami A, Badaut J, Lalas S, Ghosh N, Vlkolinsky R, Zhang $\mathrm{JH}$, Obenaus A: Brain irradiation improves focal cerebral ischemia recovery in aged rats. J Neurol Sci 2011, 306(1-2):143-153.

58. Yan LG, Lu Y, Zheng SZ, Wang AY, Li MQ, Ruan JS, Zhang L: Injectable caltrop fruit saponin protects against ischemia-reperfusion injury in rat brain. Am J Chin Med 2011, 39(2):325-333.

59. Hu Q, Ma Q, Zhan Y, He Z, Tang J, Zhou C, Zhang J: Isoflurane enhanced hemorrhagic transformation by impairing antioxidant enzymes in hyperglycemic rats with middle cerebral artery occlusion. Stroke 2011 42(6):1750-1756

60. Ahmad A, Khan MM, Hoda MN, Raza SS, Khan MB, Javed H, Ishrat T, Ashafaq M, Ahmad ME, Safhi MM, et al: Quercetin protects against oxidative stress associated damages in a rat model of transient focal cerebral ischemia and reperfusion. Neurochem Res 2011, 36(8):1360-1371.

61. Wang J, Zhao Y, Liu C, Jiang C, Zhao C, Zhu Z: Progesterone inhibits inflammatory response pathways after permanent middle cerebral artery occlusion in rats. Mol Med Report 2011, 4(2):319-324

62. Turner RJ, Helps SC, Thornton E, Vink R: A substance $P$ antagonist improves outcome when administered $4 \mathrm{~h}$ after onset of ischaemic stroke. Brain Res 2011, 1393:84-90.

63. Jiang M, Lv L, Ji H, Yang X, Zhu W, Cai L, Gu X, Chai C, Huang S, Sun J, et al: Induction of pluripotent stem cells transplantation therapy for ischemic stroke. Mol Cell Biochem 2011, 354(1-2):67-75.

64. Ay I, Sorensen $A G, A y H$ : Vagus nerve stimulation reduces infarct size in rat focal cerebral ischemia: an unlikely role for cerebral blood flow. Brain Res 2011, 1392:110-115.

65. Hirata K, Kuge Y, Yokota C, Harada A, Kokame K, Inoue H, Kawashima H, Hanzawa $\mathrm{H}$, Shono $\mathrm{Y}$, Saji $\mathrm{H}$, et al: Gene and protein analysis of brain derived neurotrophic factor expression in relation to neurological recovery induced by an enriched environment in a rat stroke model. Neurosci Lett 2011, 495(3):210-215.

66. Allahtavakoli M, Jarrott B: Sigma-1 receptor ligand PRE-084 reduced infarct volume, neurological deficits, pro-inflammatory cytokines and enhanced anti-inflammatory cytokines after embolic stroke in rats. Brain Res Bull 2011, 85(3-4):219-224.

67. Rahimian R, Daneshmand A, Mehr SE, Barzegar-Fallah A, Mohammadi-Rick S, Fakhfouri G, Shabanzadeh AP, Dehpour AR: Tropisetron ameliorates ischemic brain injury in an embolic model of stroke. Brain Res 2011, 1392:101-109.

68. Blankenship D, Niemi J, Hilow E, Karl M, Sundararajan S: Oral pioglitazone reduces infarction volume and improves neurologic function following MCAO in rats. Adv Exp Med Biol 2011, 701:157-162.

69. Chauveau F, Cho TH, Perez M, Guichardant M, Riou A, Aguettaz P, Picq M, Lagarde M, Berthezene $Y$, Nighoghossian N, et al: Brain-targeting form of docosahexaenoic acid for experimental stroke treatment: MRI evaluation and anti-oxidant impact. Curr Neurovasc Res 2011, 8(2):95-102.

70. Ma L, Zhu Z, Zhao Y, Hou L, Wang Q, Xiong L, Zhu X, Jia J, Chen S: Cannabinoid receptor type 2 activation yields delayed tolerance to focal cerebral ischemia. Curr Neurovasc Res 2011, 8(2):145-152.

71. Langdon KD, Clarke J, Corbett D: Long-term exposure to high fat diet is bad for your brain: exacerbation of focal ischemic brain injury. Neuroscience 2011, 182:82-87.

72. Belayev L, Khoutorova L, Atkins KD, Eady TN, Hong S, Lu Y, Obenaus A, Bazan NG: Docosahexaenoic Acid Therapy of Experimental Ischemic Stroke. Trans/ Stroke Res 2011, 2(1):33-41.

73. Egi Y, Matsuura S, Maruyama T, Fujio M, Yuki S, Akira T: Neuroprotective effects of a novel water-soluble poly(ADP-ribose) polymerase-1 inhibitor,
MP-124, in in vitro and in vivo models of cerebral ischemia. Brain Res 2011, 1389:169-176.

74. Svalbe B, Zvejniece L, Vavers E, Pugovics O, Muceniece R, Liepinsh E, Dambrova M: Mildronate treatment improves functional recovery following middle cerebral artery occlusion in rats. Behav Brain Res 2011, 222(1):26-32.

75. Castello-Ruiz M, Torregrosa G, Burguete MC, Salom JB, Gil JV, Miranda FJ, Jover-Mengual T, Marrachelli VG, Alborch E: Soy-derived phytoestrogens as preventive and acute neuroprotectors in experimental ischemic stroke: influence of rat strain. Phytomedicine 2011, 18(6):513-515.

76. Boyko M, Ohayon S, Goldsmith T, Novack L, Novack V, Perry ZH, Gruenbaum BF, Gruenbaum SE, Steiner O, Shapira Y, et al: Morphological and neurobehavioral parallels in the rat model of stroke. Behav Brain Res 2011, 223(1):17-23.

77. Mochizuki N, Moriyama Y, Takagi N, Takeo S, Tanonaka K: Intravenous injection of neural progenitor cells improves cerebral ischemia-induced learning dysfunction. Biol Pharm Bull 2011, 34(2):260-265.

78. Yang B, Strong R, Sharma S, Brenneman M, Mallikarjunarao K, Xi X, Grotta JC, Aronowski J, Savitz SI: Therapeutic time window and dose response of autologous bone marrow mononuclear cells for ischemic stroke. J Neurosci Res 2011, 89(6):833-839.

79. Wu XM, Qian ZM, Zhu L, Du F, Yung WH, Gong Q, Ke Y: Neuroprotective effect of ligustilide against ischaemia-reperfusion injury via upregulation of erythropoietin and down-regulation of RTP801. $\mathrm{Br} J$ Pharmacol 2011, 164(2):332-343.

80. Sun M, Zhao Y, Gu Y, Xu C: Anti-inflammatory mechanism of taurine against ischemic stroke is related to down-regulation of PARP and NFkappaB. Amino Acids 2012, 42(5):1735-1747.

81. Yao J, Xu Y, Ji F, Wang C, Zhang Y, Ni J, Wang R: Protective effects of MLIF analogs on cerebral ischemia-reperfusion injury in rats. Peptides 2011, 32(5):1047-1054

82. Zhao R, Shi WZ, Zhang YM, Fang SH, Wei EQ: Montelukast, a cysteinyl leukotriene receptor-1 antagonist, attenuates chronic brain injury after focal cerebral ischaemia in mice and rats. J Pharm Pharmacol 2011, 63(4):550-557

83. Mishra V, Verma R, Singh N, Raghubir R: The neuroprotective effects of NMDAR antagonist, ifenprodil and ASIC1a inhibitor, flurbiprofen on postischemic cerebral injury. Brain Res 2011, 1389:152-160.

84. Yang Q, Dong H, Deng J, Wang Q, Ye R, Li X, Hu S, Xiong L: Sevoflurane preconditioning induces neuroprotection through reactive oxygen species-mediated up-regulation of antioxidant enzymes in rats. Anesth Analg 2011, 112(4):931-937.

85. Liang $H$, Liu P, Wang Y, Song S, Ji A: Protective effects of alkaloid extract from Leonurus heterophyllus on cerebral ischemia reperfusion injury by middle cerebral ischemic injury (MCAO) in rats. Phytomedicine 2011, 18(10):811-818.

86. Zuhayra M, Zhao Y, von Forstner $C$, Henze E, Gohlke P, Culman J, Lutzen U: Activation of cerebral peroxisome proliferator-activated receptors gamma (PPARgamma) reduces neuronal damage in the substantia nigra after transient focal cerebral ischaemia in the rat. Neuropathol Appl Neurobiol 2011, 37(7):738-752.

87. Zhao H, Mayhan WG, Arrick DM, Xiong W, Sun H: Dose-related influence of chronic alcohol consumption on cerebral ischemia/reperfusion injury. Alcohol Clin Exp Res 2011, 35(7):1265-1269.

88. Liu HS, Shen H, Harvey BK, Castillo P, Lu H, Yang Y, Wang Y: Post-treatment with amphetamine enhances reinnervation of the ipsilateral side cortex in stroke rats. Neuroimage 2011, 56(1):280-289.

89. Zhu W, Cheng S, Xu G, Ma M, Zhou Z, Liu D, Liu X: Intranasal nerve growth factor enhances striatal neurogenesis in adult rats with focal cerebral ischemia. Drug Deliv 2011, 18(5):338-343.

90. Kam KY, Yu SJ, Jeong N, Hong JH, Jalin AM, Lee S, Choi YW, Lee CK, Kang SG: p-Hydroxybenzyl alcohol prevents brain injury and behavioral impairment by activating Nrf2, PDI, and neurotrophic factor genes in a rat model of brain ischemia. Mol Cells 2011, 31(3):209-215.

91. Han H, Xia Z, Chen H, Hou C, Li W: Simple diffusion delivery via brain interstitial route for the treatment of cerebral ischemia. Sci China Life SC 2011, 54(3):235-239.

92. Ryang YM, Fahlenkamp AV, Rossaint R, Wesp D, Loetscher PD, Beyer C, Coburn M: Neuroprotective effects of argon in an in vivo model of 
transient middle cerebral artery occlusion in rats. Crit Care Med 2011, 39(6):1448-1453.

93. Cao XL, Hu XM, Hu JQ, Zheng WX: Myocardin-related transcription factorA promoting neuronal survival against apoptosis induced by hypoxia/ ischemia. Brain Res 2011, 1385:263-274

94. Yang L, Zhang B, Yin L, Cai B, Shan H, Zhang L, Lu Y, Bi Z: Tanshinone IIA prevented brain iron dyshomeostasis in cerebral ischemic rats. Cell Physiol Biochem 2011, 27(1):23-30

95. Jiao $H$, Wang $Z$, Liu $Y$, Wang $P, X$ ue $Y$ : Specific role of tight junction proteins claudin-5, occludin, and ZO-1 of the blood-brain barrier in a focal cerebral ischemic insult. J Mol Neurosci 2011, 44(2):130-139.

96. Mao X, Yin W, Liu M, Ye M, Liu P, Liu J, Lian Q, Xu S, Pi R: Osthole, a natural coumarin, improves neurobehavioral functions and reduces infarct volume and matrix metalloproteinase- 9 activity after transient focal cerebral ischemia in rats. Brain Res 2011, 1385:275-280.

97. Lee JJ, Hsu WH, Yen TL, Chang NC, Luo YJ, Hsiao G, Sheu JR: Traditional Chinese medicine, Xue-Fu-Zhu-Yu decoction, potentiates tissue plasminogen activator against thromboembolic stroke in rats. J Ethnopharmacol 2011, 134(3):824-830.

98. Kanazawa M, Igarashi H, Kawamura K, Takahashi T, Kakita A, Takahashi H, Nakada T, Nishizawa M, Shimohata T: Inhibition of VEGF signaling pathway attenuates hemorrhage after tPA treatment. J Cereb Blood Flow Metab 2011, 31(6):1461-1474.

99. Valsecchi V, Pignataro G, Del Prete A, Sirabella R, Matrone C, Boscia F, Scorziello A, Sisalli MJ, Esposito E, Zambrano N, et al: NCX1 is a novel target gene for hypoxia-inducible factor- 1 in ischemic brain preconditioning. Stroke 2011, 42(3):754-763.

100. Chen TY, Tai SH, Lee EJ, Huang CC, Lee AC, Huang SY, Wu TS: Cinnamophilin offers prolonged neuroprotection against gray and white matter damage and improves functional and electrophysiological outcomes after transient focal cerebral ischemia. Crit Care Med 2011 39(5):1130-1137.

101. Chen J, Chen X, Qin J: Effects of polysaccharides of the Euphoria Longan (Lour.) Steud on focal cerebral ischemia/reperfusion injury and its underlying mechanism. Brain Inj 2011, 25(3):292-299.

102. Wei Y, Yemisci M, Kim HH, Yung LM, Shin HK, Hwang SK, Guo S, Qin T, Alsharif N, Brinkmann $V$, et al: Fingolimod provides long-term protection in rodent models of cerebral ischemia. Ann Neurol 2011, 69(1):119-129.

103. Lee HJ, Park J, Yoon OJ, Kim HW, Lee do Y, Kim do H, Lee WB, Lee NE, Bonventre JV, Kim SS: Amine-modified single-walled carbon nanotubes protect neurons from injury in a rat stroke model. Nat Nanotechnol 2011, 6(2):121-125.

104. Ruscher K, Shamloo M, Rickhag M, Ladunga I, Soriano L, Gisselsson L, Toresson H, Ruslim-Litrus L, Oksenberg D, Urfer R, et al: The sigma-1 receptor enhances brain plasticity and functional recovery after experimental stroke. Brain 2011, 134(Pt 3):732-746.

105. Dang J, Mitkari B, Kipp M, Beyer C: Gonadal steroids prevent cell damage and stimulate behavioral recovery after transient middle cerebral artery occlusion in male and female rats. Brain Behav Immun 2011, 25(4):715-726.

106. Park SI, Jang DK, Han YM, Sunwoo YY, Park MS, Chung YA, Maeng LS, Im R, Kim MW, Jeun SS, et al: Effect of combination therapy with sodium ozagrel and panax ginseng on transient cerebral ischemia model in rats. J Biomed Biotechnol 2010, 2010:893401.

107. Marushima A, Suzuki K, Nagasaki Y, Yoshitomi T, Toh K, Tsurushima H, Hirayama A, Matsumura A: Newly synthesized radical-containing nanoparticles enhance neuroprotection after cerebral ischemiareperfusion injury. Neurosurgery 2011, 68(5):1418-1425 discussion 1425-1416

108. Murotomi K, Takagi N, Takeo S, Tanonaka K: NADPH oxidase-mediated oxidative damage to proteins in the postsynaptic density after transient cerebral ischemia and reperfusion. Mol Cell Neurosci 2011, 46(3):681-688.

109. Sheng R, Zhang LS, Han R, Gao B, Liu XQ, Qin ZH: Combined prostaglandin E1 and lithium exert potent neuroprotection in a rat model of cerebral ischemia. Acta Pharmacol Sin 2011, 32(3):303-310.

110. Encarnacion A, Horie N, Keren-Gill H, Bliss TM, Steinberg GK, Shamloo M: Long-term behavioral assessment of function in an experimental model for ischemic stroke. J Neurosci Meth 2011, 196(2):247-257.

111. Yuan LB, Dong HL, Zhang HP, Zhao RN, Gong G, Chen XM, Zhang LN, Xiong L: Neuroprotective effect of orexin-A is mediated by an increase of hypoxia-inducible factor- 1 activity in rat. Anesthesiology 2011, 114(2):340-354
112. Yifeng $M$, Bin $W$, Weiqiao $Z$, Yongming $Q$, Bing $L$, Xiaojie L: Neuroprotective effect of sophocarpine against transient focal cerebral ischemia via down-regulation of the acid-sensing ion channel 1 in rats. Brain Res 2011, 1382:245-251.

113. Sugiyama M, lohara K, Wakita H, Hattori H, Ueda M, Matsushita K, Nakashima M: Dental pulp-derived CD31(-)/CD146(-) side population stem/ progenitor cells enhance recovery of focal cerebral ischemia in rats. Tissue Eng Part A 2011, 17(9-10):1303-1311.

114. Ye R, Zhang X, Kong X, Han J, Yang Q, Zhang Y, Chen Y, Li P, Liu J, Shi M, et al: Ginsenoside Rd attenuates mitochondrial dysfunction and sequential apoptosis after transient focal ischemia. Neuroscience 2011, 178:169-180.

115. Zhang Z, Jin D, Yang Z, Shen B, Liu M: Effects of 17 beta-estradiol pre-treated adult neural stem cells on neuronal differentiation and neurological recovery in rats with cerebral ischemia. Brain Inj 2011, 25(2):227-236.

116. Lee JS, Choi HS, Kang SW, Chung JH, Park HK, Ban JY, Kwon OY, Hong HP, Ko YG: Therapeutic effect of Korean red ginseng on inflammatory cytokines in rats with focal cerebral ischemia/reperfusion injury. Am J Chin Med 2011, 39(1):83-94.

117. Jung HW, Mahesh R, Bae HS, Kim YH, Kang JS, Park YK: The antioxidant effects of Joongpoongtang 05 on brain injury after transient focal cerebral ischemia in rats. J Nat Med 2011, 65(2):322-329.

118. Tai SH, Hung YC, Lee EJ, Lee AC, Chen TY, Shen CC, Chen HY, Lee MY, Huang SY, Wu TS: Melatonin protects against transient focal cerebral ischemia in both reproductively active and estrogen-deficient female rats: the impact of circulating estrogen on its hormetic dose-response. J Pineal Res 2011, 50(3):292-303.

119. Yang YC, Liu BS, Shen CC, Lin CH, Chiao MT, Cheng HC: Transplantation of adipose tissue-derived stem cells for treatment of focal cerebral ischemia. Curr Neurovasc Res 2011, 8(1):1-13.

120. Danielisova V, Burda J, Nemethova M, Gottlieb M: Aminoguanidine administration ameliorates hippocampal damage after middle cerebral artery occlusion in rat. Neurochem Res 2011, 36(3):476-486.

121. Wattanathorn J, Jittiwat J, Tongun T, Muchimapura S, Ingkaninan K: Zingiber officinale Mitigates Brain Damage and Improves Memory Impairment in Focal Cerebral Ischemic Rat. Evid Based Complement Alternat Med 2011, 2011:429505.

122. Wang H, Lu S, Yu Q, Liang W, Gao H, Li P, Gan Y, Chen J, Gao Y: Sevoflurane preconditioning confers neuroprotection via antiinflammatory effects. Front Biosci (Elite Ed) 2011, 3:604-615.

123. Yuan HJ, Zhu XH, Luo Q, Wu YN, Kang Y, Jiao JJ, Gao WZ, Liu YX, Lou JS: Noninvasive delayed limb ischemic preconditioning in rats increases antioxidant activities in cerebral tissue during severe ischemiareperfusion injury. J Surg Res 2012, 174(1):176-183.

124. Zhao G, Zang SY, Jiang ZH, Chen YY, Ji XH, Lu BF, Wu JH, Qin GW, Guo LH: Postischemic administration of liposome-encapsulated luteolin prevents against ischemia-reperfusion injury in a rat middle cerebral artery occlusion model. J Nutr Biochem 2011, 22(10):929-936.

125. Zhang HL, Xu M, Wei C, Qin AP, Liu CF, Hong LZ, Zhao XY, Liu J, Qin ZH: Neuroprotective effects of pioglitazone in a rat model of permanent focal cerebral ischemia are associated with peroxisome proliferatoractivated receptor gamma-mediated suppression of nuclear factorkappaB signaling pathway. Neuroscience 2011, 176:381-395.

126. Ye R, Yang Q, Kong X, Han J, Zhang X, Zhang Y, Li P, Liu J, Shi M, Xiong L, et al: Ginsenoside $\mathrm{Rd}$ attenuates early oxidative damage and sequential inflammatory response after transient focal ischemia in rats. Neurochem Int 2011, 58(3):391-398.

127. Richard MJ, Connell BJ, Khan BV, Saleh TM: Cellular mechanisms by which lipoic acid confers protection during the early stages of cerebral ischemia: a possible role for calcium. Neurosci Res 2011, 69(4):299-307.

128. Shono Y, Yokota C, Kuge Y, Kido S, Harada A, Kokame K, Inoue H, Hotta M, Hirata K, Saji H, et al: Gene expression associated with an enriched environment after transient focal ischemia. Brain Res 2011, 1376:60-65.

129. Shi GD, OuYang YP, Shi JG, Liu Y, Yuan W, Jia LS: PTEN deletion prevents ischemic brain injury by activating the mTOR signaling pathway. Biochem Biophys Res Commun 2011, 404(4):941-945.

130. Wang Q, Li X, Chen Y, Wang F, Yang Q, Chen S, Min Y, Xiong L: Activation of epsilon protein kinase $C$-mediated anti-apoptosis is involved in rapid tolerance induced by electroacupuncture pretreatment through cannabinoid receptor type 1. Stroke 2011, 42(2):389-396.

131. Mohagheghi F, Bigdeli MR, Rasoulian B, Hashemi P, Pour MR: The neuroprotective effect of olive leaf extract is related to improved blood- 
brain barrier permeability and brain edema in rat with experimental focal cerebral ischemia. Phytomedicine 2011, 18(2-3):170-175.

132. Noh SJ, Lee SH, Shin KY, Lee CK, Cho IH, Kim HS, Suh YH: SP-8203 reduces oxidative stress via SOD activity and behavioral deficit in cerebral ischemia. Pharmacol Biochem Behav 2011, 98(1):150-154.

133. Connell BJ, Saleh M, Khan BV, Saleh TM: Lipoic acid protects against reperfusion injury in the early stages of cerebral ischemia. Brain Res 2011, 1375:128-136.

134. Ramos-Cabrer P, Agulla J, Argibay B, Perez-Mato M, Castillo J: Serial MRI study of the enhanced therapeutic effects of liposome-encapsulated citicoline in cerebral ischemia. Int J Pharm 2011, 405(1-2):228-233.

135. Mohanan A, Deshpande S, Jamadarkhana PG, Kumar P, Gupta RC, Chauthaiwale V, Dutt C: Delayed intervention in experimental stroke with TRC051384-a small molecule HSP70 inducer. Neuropharmacology 2011, 60(6):991-999

136. Moyanova SG, Mastroiacovo F, Kortenska LV, Mitreva RG, Fardone E, Santolini I, Sobrado M, Battaglia G, Bruno V, Nicoletti F, et al: Protective role for type 4 metabotropic glutamate receptors against ischemic brain damage. J Cereb Blood Flow Metab 2011, 31(4):1107-1118.

137. Li Q, Li Z, Xu XY, Guo YL, Du F: Neuroprotective Properties of Picroside II in a Rat Model of Focal Cerebral Ischemia. Int J Mol Sci 2010, 11(11):4580-4590.

138. Goyagi T, Nishikawa T, Tobe $Y$ : Neuroprotective effects and suppression of ischemia-induced glutamate elevation by beta1-adrenoreceptor antagonists administered before transient focal ischemia in rats. J Neurosurg Anesthesiol 2011, 23(2):131-137.

139. Garcia-Bonilla L, Sosti V, Campos M, Penalba A, Boada C, Sumalla M, Hernandez-Guillamon M, Rosell A, Montaner J: Effects of acute posttreatment with dipyridamole in a rat model of focal cerebral ischemia. Brain Res 2011, 1373:211-220

140. Gutierrez-Fernandez M, Rodriguez-Frutos B, Alvarez-Grech J, VallejoCremades MT, Exposito-Alcaide M, Merino J, Roda JM, Diez-Tejedor E: Functional recovery after hematic administration of allogenic mesenchymal stem cells in acute ischemic stroke in rats. Neuroscience 2011, 175:394-405.

141. Qi J, Hong ZY, Xin H, Zhu YZ: Neuroprotective effects of leonurine on ischemia/reperfusion-induced mitochondrial dysfunctions in rat cerebral cortex. Biol Pharm Bull 2010, 33(12):1958-1964.

142. Genovese T, Mazzon E, Paterniti I, Esposito E, Bramanti P, Cuzzocrea S: Modulation of NADPH oxidase activation in cerebral ischemia/ reperfusion injury in rats. Brain Res 2011, 1372:92-102.

143. Adachi N, Liu K, Ninomiya K, Matsuoka E, Motoki A, Irisawa Y, Nishibori M: Reduction of the infarct size by simultaneous administration of Lhistidine and diphenhydramine in ischaemic rat brains. Resuscitation 2011, 82(2):219-221.

144. Wang SH, Li Q, Deng ZH, Ji X, Jiang X, Ge X, Bo QQ, Cui JY, Zhang LZ, Liu $\mathrm{JK}$, et al: Neanthes japonica (Iznka) fibrinolytic enzyme reduced cerebral infarction, cerebral edema and increased antioxidation in rat models of focal cerebral ischemia. Neurosci Lett 2011, 489(1):16-19.

145. Greco R, Mangione AS, Amantea D, Bagetta G, Nappi G, Tassorelli C: IkappaB-alpha expression following transient focal cerebral ischemia is modulated by nitric oxide. Brain Res 2011, 1372:145-151.

146. Yu SS, Zhao J, Lei SP, Lin XM, Wang LL, Zhao Y: 4-hydroxybenzyl alcohol ameliorates cerebral injury in rats by antioxidant action. Neurochem Res 2011, 36(2):339-346

147. Xue X, Qu XJ, Yang Y, Sheng XH, Cheng F, Jiang EN, Wang JH, Bu W, Liu ZP: Baicalin attenuates focal cerebral ischemic reperfusion injury through inhibition of nuclear factor kappaB p65 activation. Biochem Biophys Res Commun 2010, 403(3-4):398-404

148. Morimoto T, Yasuhara T, Kameda M, Baba T, Kuramoto S, Kondo A Takahashi K, Tajiri N, Wang F, Meng J, et al: Striatal stimulation nurtures endogenous neurogenesis and angiogenesis in chronic-phase ischemic stroke rats. Cell Transplant 2011, 20(7):1049-1064.

149. Riegelsberger UM, Deten A, Posel C, Zille M, Kranz A, Boltze J, Wagner DC: Intravenous human umbilical cord blood transplantation for stroke: impact on infarct volume and caspase-3-dependent cell death in spontaneously hypertensive rats. Exp Neurol 2011, 227(1):218-223.

150. Hayward NM, Yanev P, Haapasalo A, Miettinen R, Hiltunen M, Grohn O, Jolkkonen J: Chronic hyperperfusion and angiogenesis follow subacute hypoperfusion in the thalamus of rats with focal cerebral ischemia. J Cereb Blood Flow Metab 2011, 31(4):1119-1132.
151. Wu CJ, Chen JT, Yen TL, Jayakumar T, Chou DS, Hsiao G, Sheu JR: Neuroprotection by the Traditional Chinese Medicine, Tao-Hong-Si-WuTang, against Middle Cerebral Artery Occlusion-Induced Cerebral Ischemia in Rats. Evid Based Complement Alternat Med 2011, 2011:803015.

152. Koyama J, Miyake S, Sasayama T, Chiba Y, Kondoh T, Kohmura E: The novel VEGF receptor antagonist, VGA1155, reduces edema, decreases infarct and improves neurological function after stroke in rats. Kobe J Med Sci 2010, 56(1):E1-E11.

153. Qu WS, Wang YH, Ma JF, Tian DS, Zhang Q, Pan DJ, Yu ZY, Xie MJ, Wang JP, Wang W: Galectin-1 attenuates astrogliosis-associated injuries and improves recovery of rats following focal cerebral ischemia. J Neurochem 2011, 116(2):217-226

154. Chen J, Huang RB: Protective effect of Yulangsan polysaccharide on focal cerebral ischemia/reperfusion injury in rats and its underlying mechanism. Neurosciences (Riyadh) 2009, 14(4):343-348.

155. Koya-Miyata S, Ohta H, Akita K, Arai S, Ohta T, Kawata T, Fukuda S: Cyanine dyes attenuate cerebral ischemia and reperfusion injury in rats. Biol Pharm Bull 2010, 33(11):1872-1877.

156. Jin YC, Kim SW, Cheng F, Shin JH, Park JK, Lee S, Lee JE, Han PL, Lee M, Kim $\mathrm{KK}$, et al: The effect of biodegradable gelatin microspheres on the neuroprotective effects of high mobility group box $1 \mathrm{~A}$ box in the postischemic brain. Biomaterials 2011, 32(3):899-908.

157. Jiang Y, Wei N, Lu T, Zhu J, Xu G, Liu X: Intranasal brain-derived neurotrophic factor protects brain from ischemic insult via modulating local inflammation in rats. Neuroscience 2011, 172:398-405.

158. Kim JY, Jeong HY, Lee HK, Yoo JK, Bae K, Seong YH: Protective effect of llex latifolia, a major component of "kudingcha", against transient focal ischemiainduced neuronal damage in rats. J Ethnopharmacol 2011, 133(2):558-564.

159. Yeh SH, Ou LC, Gean PW, Hung JJ, Chang WC: Selective inhibition of early-but not late-expressed HIF-1alpha is neuroprotective in rats after focal ischemic brain damage. Brain Pathol 2011, 21(3):249-262.

160. O'Collins VE, Macleod MR, Cox SF, Van Raay L, Aleksoska E, Donnan GA, Howells DW: Preclinical drug evaluation for combination therapy in acute stroke using systematic review, meta-analysis, and subsequent experimental testing. J Cereb Blood Flow Metab 2011, 31(3):962-975.

161. Bao X, Wei J, Feng M, Lu S, Li G, Dou W, Ma W, Ma S, An Y, Qin C, et al: Transplantation of human bone marrow-derived mesenchymal stem cells promotes behavioral recovery and endogenous neurogenesis after cerebral ischemia in rats. Brain Res 2011, 1367:103-113.

162. Gan X, Luo Y, Ling F, Ji X, Chen J, Ding Y: Outcome in acute stroke with different intra-arterial infusion rate of urokinase on thrombolysis. Interv Neuroradiol 2010, 16(3):290-296.

163. Holm L, Theodorsson E, Hokfelt T, Theodorsson A: Effects of intracerebroventricular galanin or a galanin receptor $2 / 3$ agonist on the lesion induced by transient occlusion of the middle cerebral artery in female rats. Neuropeptides 2011, 45(1):17-23.

164. Sun L, Zhou W, Heiland S, Marti HH, Veltkamp R: A translationally relevant thromboembolic stroke model for the study of secondary hemorrhage after thrombolysis in rats. Brain Res 2011, 1368:346-354.

165. Kawai H, Deguchi S, Deguchi K, Yamashita T, Ohta Y, Shang J, Tian F, Zhang $X$, Liu N, Liu W, et al: Synergistic benefit of combined amlodipine plus atorvastatin on neuronal damage after stroke in Zucker metabolic rat. Brain Res 2011, 1368:317-323.

166. Nagel S, Heinemann PV, Heiland S, Koziol J, Gardner H, Wagner S: Selective MMP-inhibition with Ro 28-2653 in acute experimental stroke-a magnetic resonance imaging efficacy study. Brain Res 2011, 1368:264-270.

167. Bora KS, Shri R, Monga J: Cerebroprotective effect of Ocimum gratissimum against focal ischemia and reperfusion-induced cerebral injury. Pharm Biol 2011, 49(2):175-181.

168. Shang J, Deguchi K, Ohta Y, Liu N, Zhang X, Tian F, Yamashita T, Ikeda Y, Matsuura T, Funakoshi $H$, et al: Strong neurogenesis, angiogenesis, synaptogenesis, and antifibrosis of hepatocyte growth factor in rats brain after transient middle cerebral artery occlusion. J Neurosci Res 2011, 89(1):86-95.

169. Hu Q, Chen C, Khatibi NH, Li L, Yang L, Wang K, Han J, Duan W, Zhang JH, Zhou C: Lentivirus-mediated transfer of MMP-9 shRNA provides neuroprotection following focal ischemic brain injury in rats. Brain Res 2011, 1367:347-359

170. Loh KP, Qi J, Tan BK, Liu XH, Wei BG, Zhu YZ: Leonurine protects middle cerebral artery occluded rats through antioxidant effect and regulation of mitochondrial function. Stroke 2010, 41(11):2661-2668. 
171. Yuan $Y$, Guo $Q$, Ye Z, Pingping X, Wang N, Song Z: Ischemic postconditioning protects brain from ischemia/reperfusion injury by attenuating endoplasmic reticulum stress-induced apoptosis through PI3K-Akt pathway. Brain Res 2011, 1367:85-93.

172. Nakamura T, Tanaka S, Hirooka K, Toyoshima T, Kawai N, Tamiya T, Shiraga F, Tokuda M, Keep RF, Itano T, et al: Anti-oxidative effects of d-allose, a rare sugar, on ischemia-reperfusion damage following focal cerebral ischemia in rat. Neurosci Lett 2011, 487(1):103-106.

173. Cespedes-Rubio A, Jurado FW, Cardona-Gomez GP: p120 catenin/alphaNcatenin are molecular targets in the neuroprotection and neuronal plasticity mediated by atorvastatin after focal cerebral ischemia. J Neurosci Res 2010, 88(16):3621-3634.

174. Britton GL, Kim H, Kee PH, Aronowski J, Holland CK, McPherson DD, Huang SL: In vivo therapeutic gas delivery for neuroprotection with echogenic liposomes. Circulation 2010, 122(16):1578-1587.

175. Kim SJ, Kim BK, Ko YJ, Bang MS, Kim MH, Han TR: Functional and histologic changes after repeated transcranial direct current stimulation in rat stroke model. J Korean Med Sci 2010, 25(10):1499-1505.

176. Ou Y, Yu S, Kaneko Y, Tajiri N, Bae EC, Chheda SH, Stahl CE, Yang T, Fang L, Hu K, et al: Intravenous infusion of GDNF gene-modified human umbilical cord blood CD34+ cells protects against cerebral ischemic injury in spontaneously hypertensive rats. Brain Res 2010, 1366:217-225.

177. Hyun H, Lee J, Hwang do W, Kim S, Hyun DK, Choi JS, Lee JK, Lee M: Combinational therapy of ischemic brain stroke by delivery of heme oxygenase-1 gene and dexamethasone. Biomaterials 2011, 32(1):306-315

178. Jin Z, Wu J, Oh SY, Kim KW, Shin BS: The effect of stress on stroke recovery in a photothrombotic stroke animal model. Brain Res 2010, 1363:191-197.

179. Chan SJ, Wong WS, Wong PT, Bian JS: Neuroprotective effects of andrographolide in a rat model of permanent cerebral ischaemia. Br J Pharmacol 2010, 161(3):668-679.

180. Calloni RL, Winkler BC, Ricci G, Poletto MG, Homero WM, Serafini EP, Corleta OC: Transient middle cerebral artery occlusion in rats as an experimental model of brain ischemia. Acta Cir Bras 2010, 25(5):428-433.

181. Spratt NJ, Donnan GA, McLeod DD, Howells DW: 'Salvaged' stroke ischaemic penumbra shows significant injury: studies with the hypoxia tracer FMISO. J Cereb Blood Flow Metab 2011, 31(3):934-943.

182. Zhou J, Li J, Rosenbaum DM, Barone FC: Thrombopoietin protects the brain and improves sensorimotor functions: reduction of stroke-induced MMP-9 upregulation and blood-brain barrier injury. J Cereb Blood Flow Metab 2011, 31(3):924-933.

183. Chao X, Zhou J, Chen T, Liu W, Dong W, Qu Y, Jiang X, Ji X, Zhen H, Fei Z: Neuroprotective effect of osthole against acute ischemic stroke on middle cerebral ischemia occlusion in rats. Brain Res 2010, 1363:206-211.

184. Li H, Yan Z, Zhu J, Yang J, He J: Neuroprotective effects of resveratrol on ischemic injury mediated by improving brain energy metabolism and alleviating oxidative stress in rats. Neuropharmacology 2011, 60(2-3):252-258.

185. Sun M, Gu Y, Zhao Y, Xu C: Protective functions of taurine against experimental stroke through depressing mitochondria-mediated cell death in rats. Amino Acids 2011, 40(5):1419-1429.

186. Tu XK, Yang WZ, Shi SS, Chen Y, Wang CH, Chen CM, Chen Z: Baicalin inhibits TLR2/4 signaling pathway in rat brain following permanent cerebral ischemia. Inflammation 2011, 34(5):463-470.

187. Taguchi A, Zhu P, Cao F, Kikuchi-Taura A, Kasahara Y, Stern DM, Soma T, Matsuyama T, Hata R: Reduced ischemic brain injury by partial rejuvenation of bone marrow cells in aged rats. J Cereb Blood Flow Metab 2011, 31(3):855-867.

188. Zhang C, Chopp M, Cui Y, Wang L, Zhang R, Zhang L, Lu M, Szalad A,

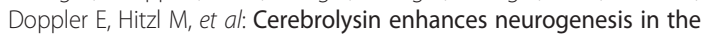
ischemic brain and improves functional outcome after stroke. $J$ Neurosci Res 2010, 88(15):3275-3281

189. Overgaard K, Rasmussen RS, Johansen FF: The site of embolization related to infarct size, oedema and clinical outcome in a rat stroke model - further translational stroke research. Exp Trans/ Stroke Med 2010, 2(1):17.

190. Lu YP, Liu SY, Sun H, Wu XM, Li JJ, Zhu L: Neuroprotective effect of astaxanthin on $\mathrm{H}(2) \mathrm{O}(2)$-induced neurotoxicity in vitro and on focal cerebral ischemia in vivo. Brain Res 2010, 1360:40-48.

191. Han Z, Zhang HX, Tian JS, Zheng RY, Hou ST: 2-(-2-benzofuranyl)-2imidazoline induces $\mathrm{BCl}-2$ expression and provides neuroprotection against transient cerebral ischemia in rats. Brain Res 2010, 1361:86-92.
192. Cao W, Glushakov A, Shah HP, Mecca AP, Sumners C, Shi P, Seubert CN, Martynyuk AE: Halogenated aromatic amino acid 3,5-dibromo-D: tyrosine produces beneficial effects in experimental stroke and seizures. Amino Acids 2011, 40(4):1151-1158.

193. Jiang W, Zhang S, Fu F, Zhu H, Hou J: Inhibition of nuclear factor-kappaB by 6-O-acetyl shanzhiside methyl ester protects brain against injury in a rat model of ischemia and reperfusion. J Neuroinflammation 2010, 7:55

194. Hou YC, Liou KT, Chern CM, Wang YH, Liao JF, Chang S, Chou YH, Shen YC: Preventive effect of silymarin in cerebral ischemia-reperfusion-induced brain injury in rats possibly through impairing NF-kappaB and STAT-1 activation. Phytomedicine 2010, 17(12):963-973.

195. Fu A, Hui EK, Lu JZ, Boado RJ, Pardridge WM: Neuroprotection in experimental stroke in the rat with an IgG-erythropoietin fusion protein. Brain Res 2010, 1360:193-197.

196. Hyun H, Won YW, Kim KM, Lee J, Lee M, Kim YH: Therapeutic effects of a reducible poly (oligo-D-arginine) carrier with the heme oxygenase-1 gene in the treatment of hypoxic-ischemic brain injury. Biomaterials 2010, 31(34):9128-9134.

197. Wang T, Wang J, Yin C, Liu R, Zhang JH, Qin X: Down-regulation of Nogo receptor promotes functional recovery by enhancing axonal connectivity after experimental stroke in rats. Brain Res 2010, 1360:147-158.

198. Karki K, Knight RA, Shen LH, Kapke A, Lu M, Li Y, Chopp M: Chronic brain tissue remodeling after stroke in rat: a 1-year multiparametric magnetic resonance imaging study. Brain Res 2010, 1360:168-176.

199. Ishrat T, Sayeed I, Atif F, Hua F, Stein DG: Progesterone and allopregnanolone attenuate blood-brain barrier dysfunction following permanent focal ischemia by regulating the expression of matrix metalloproteinases. Exp Neurol 2010, 226(1):183-190.

200. Wang CC, Chio CC, Chang CH, Kuo JR, Chang CP: Beneficial effect of agmatine on brain apoptosis, astrogliosis, and edema after rat transient cerebral ischemia. BMC Pharmacol 2010, 10:11

201. Mishra V, Verma R, Raghubir R: Neuroprotective effect of flurbiprofen in focal cerebral ischemia: the possible role of ASIC1a. Neuropharmacology 2010, 59(7-8):582-588.

202. Du W, Huang J, Yao H, Zhou K, Duan B, Wang Y: Inhibition of TRPC6 degradation suppresses ischemic brain damage in rats. J Clin Invest 2010, 120(10):3480-3492.

203. Hwang SY, Shin JH, Hwang JS, Kim SY, Shin JA, Oh ES, Oh S, Kim JB, Lee JK Han IO: Glucosamine exerts a neuroprotective effect via suppression of inflammation in rat brain ischemia/reperfusion injury. Glia 2010, 58(15):1881-1892.

204. Jiang WL, Zhang SP, Zhu HB, Hou J: Effect of 8-O-acetyl shanzhiside methylester increases angiogenesis and improves functional recovery after stroke. Basic Clin Pharmacol Toxicol 2011, 108(1):21-27.

205. Matsuda F, Sakakima H, Yoshida Y: The effects of early exercise on brain damage and recovery after focal cerebral infarction in rats. Acta Physiol (Oxf) 2011, 201(2):275-287.

206. Luckl J, Baker W, Sun ZH, Durduran T, Yodh AG, Greenberg JH: The biological effect of contralateral forepaw stimulation in rat focal cerebral ischemia: a multispectral optical imaging study. Front Neuroenergetics 2010, 2:pii: 19.

207. Li W, Kelly-Cobbs Al, Mezzetti EM, Fagan SC, Ergul A: Endothelin-1-mediated cerebrovascular remodeling is not associated with increased ischemic brain injury in diabetes. Can J Physiol Pharmacol 2010, 88(8):788-795.

208. Ding G, Jiang Q, Li L, Zhang L, Wang Y, Zhang ZG, Lu M, Panda S, Li O Ewing $J R$, et al: Cerebral tissue repair and atrophy after embolic stroke in rat: a magnetic resonance imaging study of erythropoietin therapy. J Neurosci Res 2010, 88(14):3206-3214.

209. Cheyuo C, Wu R, Zhou M, Jacob A, Coppa G, Wang P: Ghrelin suppresses inflammation and neuronal nitric oxide synthase in focal cerebral ischemia via the vagus nerve. Shock 2011, 35(3):258-265.

210. Zhang F, Jia J, Wu Y, Hu Y, Wang Y: The effect of treadmill training preexercise on glutamate receptor expression in rats after cerebral ischemia. Int J Mol Sci 2010, 11(7):2658-2669.

211. Chong ZZ, Shang YC, Hou J, Maiese K: Wnt1 neuroprotection translates into improved neurological function during oxidant stress and cerebral ischemia through AKT1 and mitochondrial apoptotic pathways. Oxid Med Cell Longev 2010, 3(2):153-165.

212. Zhang F, Wu Y, Jia J, Hu YS: Pre-ischemic treadmill training induces tolerance to brain ischemia: involvement of glutamate and ERK1/2. Molecules 2010, 15(8):5246-5257. 
213. Menn B, Bach S, Blevins TL, Campbell M, Meijer L, Timsit S: Delayed treatment with systemic (S)-roscovitine provides neuroprotection and inhibits in vivo CDK5 activity increase in animal stroke models. PLoS One 2010, 5(8):e12117.

214. Wang JK, Yu LN, Zhang FJ, Yang MJ, Yu J, Yan M, Chen G: Postconditioning with sevoflurane protects against focal cerebral ischemia and reperfusion injury via PI3K/Akt pathway. Brain Res 2010, 1357:142-151.

215. Yao H, Nabika T: Characterizing photothrombotic distal middle cerebral artery occlusion and YAG laser-induced reperfusion model in the Izumo strain of spontaneously hypertensive rats. Cell Mol Neurobiol 2011, 31(1):57-63.

216. Savos AV, Gee JM, Zierath D, Becker KJ: alpha-MSH: a potential neuroprotective and immunomodulatory agent for the treatment of stroke. J Cereb Blood Flow Metab 2011, 31(2):606-613.

217. Leasure $J$, Grider M: The effect of mild post-stroke exercise on reactive neurogenesis and recovery of somatosensation in aged rats. Exp Neurol 2010, 226(1):58-67.

218. Gamboa J, Blankenship DA, Niemi JP, Landreth GE, Karl M, Hilow E, Sundararajan S: Extension of the neuroprotective time window for thiazolidinediones in ischemic stroke is dependent on time of reperfusion. Neuroscience 2010, 170(3):846-857.

219. Airavaara M, Chiocco MJ, Howard DB, Zuchowski KL, Peranen J, Liu C, Fang S, Hoffer BJ, Wang Y, Harvey BK: Widespread cortical expression of MANF by AAV serotype 7: localization and protection against ischemic brain injury. Exp Neurol 2010, 225(1):104-113.

220. Rong ZT, Gong XJ, Sun HB, Li YM, Ji H: Protective effects of oleanolic acid on cerebral ischemic damage in vivo and $\mathrm{H}(2) \mathrm{O}(2)$-induced injury in vitro. Pharm Biol 2011, 49(1):78-85.

221. Zhang Y, Xing S, Zhang J, Li J, Li C, Pei Z, Zeng J: Reduction of betaamyloid deposits by gamma-secretase inhibitor is associated with the attenuation of secondary damage in the ipsilateral thalamus and sensory functional improvement after focal cortical infarction in hypertensive rats. J Cereb Blood Flow Metab 2011, 31(2):572-579.

222. Guluma KZ, Lapchak PA: Comparison of the post-embolization effects of tissue-plasminogen activator and simvastatin on neurological outcome in a clinically relevant rat model of acute ischemic stroke. Brain Res 2010 1354:206-216

223. Jia L, Chopp M, Zhang L, Lu M, Zhang Z: Erythropoietin in combination of tissue plasminogen activator exacerbates brain hemorrhage when treatment is initiated 6 hours after stroke. Stroke 2010, 41(9):2071-2076.

224. Farr TD, Seehafer JU, Nelles M, Hoehn M: Challenges towards MR imaging of the peripheral inflammatory response in the subacute and chronic stages of transient focal ischemia. NMR Biomed 2011, 24(1):35-45.

225. Narantuya D, Nagai A, Sheikh AM, Masuda J, Kobayashi S, Yamaguchi S, Kim SU: Human microglia transplanted in rat focal ischemia brain induce neuroprotection and behavioral improvement. PLOS One 2010, 5(7):e11746.

226. Hu B, Wang Q, Chen Y, Du J, Zhu X, Lu Y, Xiong L, Chen S: Neuroprotective effect of WIN 55,212-2 pretreatment against focal cerebral ischemia through activation of extracellular signal-regulated kinases in rats. Eur $J$ Pharmacol 2010, 645(1-3):102-107.

227. Zhao H, Mayhan WG, Arrick DM, Xiong W, Sun H: Alcohol-induced exacerbation of ischemic brain injury: role of $\mathrm{NAD}(\mathrm{P}) \mathrm{H}$ oxidase. Alcohol Clin Exp Res 2010, 34(11):1948-1955.

228. Du J, Wang Q, Hu B, Peng Z, Zhao Y, Ma L, Xiong L, Lu Y, Zhu X, Chen S: Involvement of ERK $1 / 2$ activation in electroacupuncture pretreatment via cannabinoid CB1 receptor in rats. Brain Res 2010, 1360:1-7.

229. Pei L, Zhang Y, Chu X, Zhang J, Wang R, Liu M, Zhu X, Yu W: Peroxisome proliferator-activated receptor gamma promotes neuroprotection by modulating cyclin D1 expression after focal cerebral ischemia. Can J Physiol Pharmacol 2010, 88(7):716-723.

230. Letourneur A, Roussel S, Toutain J, Bernaudin M, Touzani O: Impact of genetic and renovascular chronic arterial hypertension on the acute spatiotemporal evolution of the ischemic penumbra: a sequential study with MRI in the rat. J Cereb Blood Flow Metab 2011, 31(2):504-513.

231. Kim J, Kim MY, Leem KH, Moon S, Jamakattel-Pandit N, Choi H, Kim H, Bu Y: Key compound groups for the neuroprotective effect of roots of Polygonum cuspidatum on transient middle cerebral artery occlusion in Sprague-Dawley rats. Nat Prod Res 2010, 24(13):1214-1226.

232. Briyal S, Gulati A: Endothelin-A receptor antagonist BQ123 potentiates acetaminophen induced hypothermia and reduces infarction following focal cerebral ischemia in rats. Eur J Pharmacol 2010, 644(1-3):73-79.
233. Wang W, Xu J, Li L, Wang P, Ji X, Ai H, Zhang L: Neuroprotective effect of morroniside on focal cerebral ischemia in rats. Brain Res Bull 2010, 83(5):196-201

234. Cui L, Zhang X, Yang R, Liu L, Wang L, Li M, Du W: Baicalein is neuroprotective in rat MCAO model: role of 12/15-lipoxygenase, mitogen-activated protein kinase and cytosolic phospholipase A2. Pharmacol Biochem Behav 2010, 96(4):469-475.

235. Yuan Z, Liu W, Liu B, Schnell A, Liu KJ: Normobaric hyperoxia delays and attenuates early nitric oxide production in focal cerebral ischemic rats. Brain Res 2010, 1352:248-254

236. Jalal FY, Bohlke M, Maher TJ: Acetyl-L-carnitine reduces the infarct size and striatal glutamate outflow following focal cerebral ischemia in rats. Ann N Y Acad Sci 2010, 1199:95-104.

237. Pino-Figueroa A, Nguyen D, Maher TJ: Neuroprotective effects of Lepidium meyenii (Maca). Ann N Y Acad Sci 2010, 1199:77-85.

238. Ma Y, Sullivan JC, Schreihofer DA: Dietary genistein and equol (4', 7 isoflavandiol) reduce oxidative stress and protect rats against focal cerebral ischemia. Am J Physiol Regul Integr Comp Physiol 2010, 299(3):R871-R877.

239. Pignataro G, Esposito E, Cuomo O, Sirabella R, Boscia F, Guida N, Di Renzo $\mathrm{G}$, Annunziato L: The NCX3 isoform of the $\mathrm{Na}+/ \mathrm{Ca} 2+$ exchanger contributes to neuroprotection elicited by ischemic postconditioning J Cereb Blood Flow Metab 2011, 31(1):362-370.

240. Sepramaniam S, Armugam A, Lim KY, Karolina DS, Swaminathan P, Tan JR, Jeyaseelan K: MicroRNA 320a functions as a novel endogenous modulator of aquaporins 1 and 4 as well as a potential therapeutic target in cerebral ischemia. J Biol Chem 2010, 285(38):29223-29230.

241. Morris DC, Chopp M, Zhang L, Lu M, Zhang ZG: Thymosin beta4 improves functional neurological outcome in a rat model of embolic stroke. Neuroscience 2010, 169(2):674-682.

242. Cui L, Zhang X, Yang R, Wang L, Liu L, Li M, Du W: Neuroprotection and underlying mechanisms of oxymatrine in cerebral ischemia of rats. Neurol Res 2011, 33(3):319-324.

243. Gao B, Cam E, Jaeger H, Zunzunegui C, Sarnthein J, Bassetti CL: Sleep disruption aggravates focal cerebral ischemia in the rat. Sleep 2010, 33(7):879-887.

244. Zhang ZG, Lu TS, Yuan HY: Neuroprotective effects of ultra-low-molecularweight heparin in vitro and vivo models of ischemic injury. Fundam Clin Pharmacol 2011, 25(3):300-303.

245. Choi HS, Ko YG, Lee JS, Kwon OY, Kim SK, Cheong C, Jang KH, Kang SA Neuroprotective effects of consuming bovine colostrum after focal brain ischemia/reperfusion injury in rat model. Nutr Res Pract 2010, 4(3):196-202.

246. Mohagheghi F, Bigdeli MR, Rasoulian B, Zeinanloo AA, Khoshbaten A: Dietary virgin olive oil reduces blood brain barrier permeability, brain edema, and brain injury in rats subjected to ischemia-reperfusion. $\mathrm{SCi}$ World J 2010, 10:1180-1191.

247. Yuen CM, Leu S, Lee FY, Yen CH, Lin YC, Chua S, Chung SY, Chai HT, Sheu JJ, Ko SF, et al: Erythropoietin markedly attenuates brain infarct size and improves neurological function in the rat. J Investig Med 2010, 58(7):893-904.

248. Xiang J, Tang YP, Wu P, Gao JP, Cai DF: Chinese medicine Nao-Shuan-Tong attenuates cerebral ischemic injury by inhibiting apoptosis in a rat model of stroke. J Ethnopharmacol 2010, 131(1):174-181.

249. Zhou ZY, Tang YP, Xiang J, Wua P, Jin HM, Wang Z, Mori M, Cai DF: Neuroprotective effects of water-soluble Ganoderma lucidum polysaccharides on cerebral ischemic injury in rats. J Ethnopharmacol 2010, 131(1):154-164.

250. Kitamura E, Hamada J, Kanazawa N, Yonekura J, Masuda R, Sakai F, Mochizuki $\mathrm{H}$ : The effect of orexin-A on the pathological mechanism in the rat focal cerebral ischemia. Neurosci Res 2010, 68(2):154-157.

251. Senda DM, Franzin S, Mori MA, de Oliveira RM, Milani H: Acute, postischemic sensorimotor deficits correlate positively with infarct size but fail to predict its occurrence and magnitude after middle cerebral artery occlusion in rats. Behav Brain Res 2011, 216(1):29-35.

252. Zhang H, Bi F, Xiao C, Liu J, Wang Z, Liu JN, Zhang J: The Kringle-2 domain of tissue plasminogen activator significantly reduces mortality and brain infarction in middle cerebral artery occlusion rats. Int J Mol Med 2010, 26(2):225-230.

253. Kondoh T, Kameishi M, Mallick HN, Ono T, Torii K: Lysine and arginine reduce the effects of cerebral ischemic insults and inhibit glutamateinduced neuronal activity in rats. Front Integr Neurosci 2010, 4:18.

254. Cheng J, Uchida M, Zhang W, Grafe MR, Herson PS, Hurn PD: Role of saltinduced kinase 1 in androgen neuroprotection against cerebral ischemia. J Cereb Blood Flow Metab 2011, 31(1):339-350. 
255. Lay CC, Davis MF, Chen-Bee CH, Frostig RD: Mild sensory stimulation completely protects the adult rodent cortex from ischemic stroke. PLOS One 2010, 5(6):e11270.

256. Tang C, Xue H, Bai C, Fu R, Wu A: The effects of Tanshinone IIA on bloodbrain barrier and brain edema after transient middle cerebral artery occlusion in rats. Phytomedicine 2010, 17(14):1145-1149.

257. Shen CC, Lin CH, Yang YC, Chiao MT, Cheng WY, Ko JL: Intravenous implanted neural stem cells migrate to injury site, reduce infarct volume, and improve behavior after cerebral ischemia. Curr Neurovasc Res 2010, 7(3):167-179.

258. Shehadah A, Chen J, Zacharek A, Cui Y, Ion M, Roberts C, Kapke A, Chopp $\mathrm{M}$ : Niaspan treatment induces neuroprotection after stroke. Neurobiol Dis 2010, 40(1):277-283

259. Cho GW, Koh SH, Kim MH, Yoo AR, Noh MY, Oh S, Kim SH: The neuroprotective effect of erythropoietin-transduced human mesenchymal stromal cells in an animal model of ischemic stroke. Brain Res 2010, 1353:1-13.

260. Tang X, Liu KJ, Ramu J, Chen Q, Li T, Liu W: Inhibition of gp91(phox) contributes towards normobaric hyperoxia afforded neuroprotection in focal cerebral ischemia. Brain Res 2010, 1348:174-180.

261. Oyama N, Yagita Y, Sasaki T, Omura-Matsuoka E, Terasaki Y, Sugiyama Y, Sakoda S, Kitagawa K: An angiotensin II type 1 receptor blocker can preserve endothelial function and attenuate brain ischemic damage in spontaneously hypertensive rats. J Neurosci Res 2010, 88(13):2889-2898.

262. Jia J, Hu YS, Wu Y, Yu HX, Liu G, Zhu DN, Xia CM, Cao ZJ, Zhang X, Guo QC: Treadmill pre-training suppresses the release of glutamate resulting from cerebral ischemia in rats. Exp Brain Res 2010, 204(2):173-179.

263. Moubarik C, Guillet B, Youssef B, Codaccioni JL, Piercecchi MD, Sabatier F Lionel P, Dou L, Foucault-Bertaud A, Velly L, et al: Transplanted late outgrowth endothelial progenitor cells as cell therapy product for stroke. Stem Cell Rev 2011, 7(1):208-220

264. Lapergue B, Moreno JA, Dang BQ, Coutard M, Delbosc S, Raphaeli G, Auge $\mathrm{N}$, Klein I, Mazighi M, Michel JB, et al: Protective effect of high-density lipoprotein-based therapy in a model of embolic stroke. Stroke 2010, 41(7):1536-1542.

265. Homi HM, Sheng H, Arepally GM, Mackensen GB, Grocott HP: Aprotinin improves functional outcome but not cerebral infarct size in an experimental model of stroke during cardiopulmonary bypass. Anesth Analg 2010, 111(1):38-45.

266. Bar-Shir A, Shemesh N, Nossin-Manor R, Cohen Y: Late stimulation of the sphenopalatine-ganglion in ischemic rats: improvement in $\mathrm{N}$-acetyl -aspartate levels and diffusion weighted imaging characteristics as seen by MR. J Magn Reson Imaging 2010, 31(6):1355-1363.

267. Saad MA, Abbas AM, Boshra V, Elkhateeb M, El Aal IA: Effect of angiotensin II type 1 receptor blocker, candesartan, and beta 1 adrenoceptor blocker, atenolol, on brain damage in ischemic stroke. Acta Physiol Hung 2010, 97(2):159-171.

268. Beltran EJ, Papadopoulos CM, Tsai SY, Kartje GL, Wolf WA: Long-term motor improvement after stroke is enhanced by short-term treatment with the alpha-2 antagonist, atipamezole. Brain Res 2010, 1346:174-182.

269. Yin YY, Li WP, Gong HL, Zhu FF, Li WZ, Wu GC: Protective effect of astragaloside on focal cerebral ischemia/reperfusion injury in rats. Am J Chin Med 2010, 38(3):517-527.

270. Kao TK, Ou YC, Raung SL, Chen WY, Yen YJ, Lai CY, Chou ST, Chen CJ: Graptopetalum paraguayense E. Walther leaf extracts protect against brain injury in ischemic rats. Am J Chin Med 2010, 38(3):495-516.

271. Xiao X, Liu Y, Qi C, Qiu F, Chen X, Zhang J, Yang P: Neuroprotection and enhanced neurogenesis by tetramethylpyrazine in adult rat brain after focal ischemia. Neurol Res 2010, 32(5):547-555.

272. Kim YK, Leem JG, Sim JY, Jeong SM, Joung KW: The effects of gabapentin pretreatment on brain injury induced by focal cerebral ischemia/ reperfusion in the rat. Korean J Anesthesio/ 2010, 58(2):184-190.

273. Kim YK, Leem JG, Shin JW, Joung KW: Ischemic postconditioning may not influence early brain injury induced by focal cerebral ischemia/ reperfusion in rats. Korean J Anesthesiol 2010, 58(2):176-183.

274. Pratap R, Pillai KK, Khanam R, Islam F, Ahmad SJ, Akhtar M: Protective effect of irbesartan, an angiotensin II receptor antagonist, alone and in combination with aspirin on middle cerebral artery occlusion model of focal cerebral ischemia in rats. Hum Exp Toxicol 2011, 30(5):354-362.

275. Tang LL, Zheng JS: Effects of tetrahydrobiopterin on cerebral infarction after transient focal ischemia in rats. Neurol Res 2011, 33(10):1064-1067.
276. Klaus JA, Kibler KK, Abuchowski A, Koehler RC: Early treatment of transient focal cerebral ischemia with bovine PEGylated carboxy hemoglobin transfusion. Artif Cells Blood Substit Immobil Biotechnol 2010 38(5):223-229.

277. Ren L, Wang YK, Fang YN, Zhang AW, Li XL: Effect of electroacupuncture therapy on the expression of $\mathrm{Na}(\mathrm{v}) 1.1$ and $\mathrm{Na}(\mathrm{v}) 1.6$ in rat after acute cerebral ischemia. Neurol Res 2010, 32(10):1110-1116.

278. Wang F, Luo $Y$, Ling F, Wu H, Chen J, Yan F, He Z, Goel G, Ji X, Ding Y: Comparison of neuroprotective effects in ischemic rats with different hypothermia procedures. Neurol Res 2010, 32(4):378-383.

279. Peng S, Kuang Z, Zhang Y, Xu H, Cheng Q: The protective effects and potential mechanism of Calpain inhibitor Calpeptin against focal cerebral ischemia-reperfusion injury in rats. Mol Biol Rep 2011, 38(2):905-912.

280. Kawanishi K, Koshino H, Toyoshita Y, Tanaka M, Hirai T: Effect of mastication on functional recoveries after permanent middle cerebral artery occlusion in rats. J Stroke Cerebrovasc Dis 2010, 19(5):398-403.

281. Jiang WL, Tian JW, Fu FH, Zhu HB, Hou J: Neuroprotective efficacy and therapeutic window of Forsythoside $B$ : in a rat model of cerebral ischemia and reperfusion injury. Eur J Pharmacol 2010, 640(1-3):75-81.

282. Chang CZ, Kwan AL, Howng SL: 6-Mercaptopurine exerts an immunomodulatory and neuroprotective effect on permanent focal cerebral occlusion in rats. Acta Neurochir (Wien) 2010, 152(8):1383-1390. discussion 1390

283. Goyagi T, Horiguchi T, Nishikawa T, Tobe Y: Post-treatment with selective beta1 adrenoceptor antagonists provides neuroprotection against transient focal ischemia in rats. Brain Res 2010, 1343:213-217.

284. Shehadah A, Chen J, Cui X, Roberts C, Lu M, Chopp M: Combination treatment of experimental stroke with Niaspan and Simvastatin, reduces axonal damage and improves functional outcome. J Neurol Sci 2010, 294(1-2):107-111.

285. Zhang S, Liu Y, Zhao Z, Xue Y: Effects of green tea polyphenols on caveolin-1 of microvessel fragments in rats with cerebral ischemia. Neurol Res 2010, 32(9):963-970.

286. Bora KS, Sharma A: Neuroprotective effect of Artemisia absinthium L. on focal ischemia and reperfusion-induced cerebral injury. J Ethnopharmacol 2010, 129(3):403-409.

287. Connell BJ, Saleh TM: A novel rodent model of reperfusion injury following occlusion of the middle cerebral artery. J Neurosci Meth 2010, 190(1):28-33.

288. Cai H, Xu X, Liu Z, Wang Q, Feng G, Li Y, Xu C, Liu G, Li Z: The effects of calcitonin gene-related peptide on bFGF and AQP4 expression after focal cerebral ischemia reperfusion in rats. Pharmazie 2010, 65(4):274-278.

289. Hung YC, Chou YS, Chang CH, Lin HW, Chen HY, Chen TY, Tai SH, Lee EJ: Early reperfusion improves the recovery of contralateral electrophysiological diaschisis following focal cerebral ischemia in rats. Neurol Res 2010, 32(8):828-834.

290. Sun L, Zhou W, Mueller C, Sommer C, Heiland S, Bauer AT, Marti HH, Veltkamp R: Oxygen therapy reduces secondary hemorrhage after thrombolysis in thromboembolic cerebral ischemia. J Cereb Blood Flow Metab 2010, 30(9):1651-1660

291. Chen CH, Manaenko A, Zhan Y, Liu WW, Ostrowki RP, Tang J, Zhang JH: Hydrogen gas reduced acute hyperglycemia-enhanced hemorrhagic transformation in a focal ischemia rat model. Neuroscience 2010, 169(1):402-414.

292. Verma R, Mishra V, Sasmal D, Raghubir R: Pharmacological evaluation of glutamate transporter 1 (GLT-1) mediated neuroprotection following cerebral ischemia/reperfusion injury. Eur J Pharmacol 2010, 638(1-3):65-71.

293. Osmond JM, Mintz JD, Stepp DW: Preventing increased blood pressure in the obese Zucker rat improves severity of stroke. Am J Physiol Heart Circ Physiol 2010, 299(1):H55-H61.

294. Liu L, Zhang X, Wang L, Yang R, Cui L, Li M, Du W, Wang S: The neuroprotective effects of Tanshinone IIA are associated with induced nuclear translocation of TORC1 and upregulated expression of TORC1, PCREB and BDNF in the acute stage of ischemic stroke. Brain Res Bull 2010, 82(3-4):228-233.

295. Zhang X, Deguchi K, Yamashita T, Ohta Y, Shang J, Tian F, Liu N, Panin VL, Ikeda Y, Matsuura T, et al: Temporal and spatial differences of multiple protein expression in the ischemic penumbra after transient MCAO in rats. Brain Res 2010, 1343:143-152.

296. Emerich DF, Silva E, Ali O, Mooney D, Bell W, Yu SJ, Kaneko Y, Borlongan C: Injectable VEGF hydrogels produce near complete neurological and anatomical protection following cerebral ischemia in rats. Cell Transplant 2010, 19(9):1063-1071. 
297. Greenhalgh AD, Galea J, Denes A, Tyrrell PJ, Rothwell NJ: Rapid brain penetration of interleukin-1 receptor antagonist in rat cerebral ischaemia: pharmacokinetics, distribution, protection. Br J Pharmacol 2010, 160(1):153-159.

298. Lin GH, Lin L, Liang HW, Ma X, Wang JY, Wu LP, Jiang HD, Bruce IC, Xia Q: Antioxidant action of a Chrysanthemum morifolium extract protects rat brain against ischemia and reperfusion injury. J Med Food 2010, 13(2):306-311.

299. Zhuang $P$, Ji H, Zhang YH, Min ZL, Ni QG, You R: ZJM-289, a novel nitric oxide donor, alleviates the cerebral ischaemic-reperfusion injury in rats. Clin Exp Pharmacol Physiol 2010, 37(3):e121-e127.

300. Lim SH, Kim HS, Kim YK, Kim TM, Im S, Chung ME, Hong BY, Ko YJ, Kim HW, Lee Jl: The functional effect of epigallocatechin gallate on ischemic stroke in rats. Acta Neurobiol Exp (Wars) 2010, 70(1):40-46.

301. Porritt MJ, Chen M, Rewell SS, Dean RG, Burrell LM, Howells DW: ACE inhibition reduces infarction in normotensive but not hypertensive rats: correlation with cortical ACE activity. J Cereb Blood Flow Metab 2010, 30(8):1520-1526.

302. Nagel S, Papadakis M, Chen R, Hoyte LC, Brooks KJ, Gallichan D, Sibson NR, Pugh C, Buchan AM: Neuroprotection by dimethyloxalylglycine following permanent and transient focal cerebral ischemia in rats. J Cereb Blood Flow Metab 2011, 31(1):132-143.

303. Nategh M, Shaveisi K, Shabanzadeh AP, Sadr S, Parviz M, Ghabaei M: Systemic hyperthermia masks the neuroprotective effects of MK-801, but not rosiglitazone in brain ischaemia. Basic Clin Pharmacol Toxicol 2010, 107(3):724-729.

304. Wu Y, Ye XH, Guo PP, Xu SP, Wang J, Yuan SY, Yao SL, Shang Y: Neuroprotective effect of lipoxin A4 methyl ester in a rat model of permanent focal cerebral ischemia. J Mol Neurosci 2010, 42(2):226-234

305. Zhang T, Pan BS, Sun GC, Sun X, Sun FY: Diabetes synergistically exacerbates poststroke dementia and tau abnormality in brain. Neurochem Int 2010, 56(8):955-961.

306. Kollmar R, Henninger N, Urbanek C, Schwab S: G-CSF, rt-PA and combination therapy after experimental thromboembolic stroke. Exp Trans/ Stroke Med 2010, 2:9.

307. Tu XK, Yang WZ, Shi SS, Wang CH, Zhang GL, Ni TR, Chen CM, Wang R, Jia $J W$, Song QM: Spatio-temporal distribution of inflammatory reaction and expression of TLR2/4 signaling pathway in rat brain following permanent focal cerebral ischemia. Neurochem Res 2010, 35(8):1147-1155.

308. Martin A, Boisgard R, Kassiou M, Dolle F, Tavitian B: Reduced PBR/TSPO expression after minocycline treatment in a rat model of focal cerebral ischemia: a PET study using [(18)F]DPA-714. Mol Imaging Biol 2011, 13(1):10-15.

309. Komatsu K, Honmou O, Suzuki J, Houkin K, Hamada H, Kocsis JD: Therapeutic time window of mesenchymal stem cells derived from bone marrow after cerebral ischemia. Brain Res 2010, 1334:84-92.

310. Kelsen J, Larsen MH, Sorensen JC, Moller A, Frokiaer J, Nielsen S, Nyengaard JR, Mikkelsen JD, Ronn LC: Neuronal precursor cell proliferation in the hippocampus after transient cerebral ischemia: a comparative study of two rat strains using stereological tools. Exp Trans/ Stroke Med 2010, 2:8.

311. Plotnikov EY, Silachev DN, Chupyrkina AA, Danshina MI, Jankauskas SS, Morosanova MA, Stelmashook EV, Vasileva AK, Goryacheva ES, Pirogov YA, et al: New-generation Skulachev ions exhibiting nephroprotective and neuroprotective properties. Biochemistry (Mosc) 2010, 75(2):145-150.

312. Popa-Wagner A, Stocker K, Balseanu AT, Rogalewski A, Diederich K, Minnerup J, Margaritescu C, Schabitz WR: Effects of granulocyte-colony stimulating factor after stroke in aged rats. Stroke 2010, 41(5):1027-1031.

313. Li L, Ke Z, Tong KY, Ying M: Evaluation of cerebral blood flow changes in focal cerebral ischemia rats by using transcranial Doppler ultrasonography. Ultrasound Med Biol 2010, 36(4):595-603.

314. Langdon KD, Maclellan CL, Corbett D: Prolonged, 24-h delayed peripheral inflammation increases short- and long-term functional impairment and histopathological damage after focal ischemia in the rat. $J$ Cereb Blood Flow Metab 2010, 30(8):1450-1459.

315. Homi HM, Jones WL, de Lange F, Mackensen GB, Grocott HP: Exacerbation of systemic inflammation and increased cerebral infarct volume with cardiopulmonary bypass after focal cerebral ischemia in the rat. $J$ Thorac Cardiovasc Surg 2010, 140(3):660-666. 666 e661.

316. Strom JO, Theodorsson E, Holm L, Theodorsson A: Different methods for administering 17 beta-estradiol to ovariectomized rats result in opposite effects on ischemic brain damage. BMC Neurosci 2010, 11:39.

317. Burggraf D, Vosko MR, Schubert M, Stassen JM, Hamann GF: Different therapy options protecting microvasculature after experimental cerebral ischaemia and reperfusion. Thromb Haemost 2010, 103(5):891-900.
318. Haelewyn B, Risso JJ, Abraini JH: Human recombinant tissue-plasminogen activator (alteplase): why not use the 'human' dose for stroke studies in rats? J Cereb Blood Flow Metab 2010, 30(5):900-903.

319. Abe E, Fujiki M, Nagai $Y$, Shiqi K, Kubo T, Ishii K, Abe T, Kobayashi H: The phosphatidylinositol-3 kinase/Akt pathway mediates geranylgeranylacetone-induced neuroprotection against cerebral infarction in rats. Brain Res 2010, 1330:151-157.

320. Tu XK, Yang WZ, Wang $C H$, Shi SS, Zhang YL, Chen CM, Yang YK, Jin CD, Wen S: Zileuton reduces inflammatory reaction and brain damage following permanent cerebral ischemia in rats. Inflammation 2010, 33(5):344-352.

321. Zhang L, Zhang ZG, Buller B, Jiang J, Jiang Y, Zhao D, Liu X, Morris D, Chopp M: Combination treatment with VELCADE and low-dose tissue plasminogen activator provides potent neuroprotection in aged rats after embolic focal ischemia. Stroke 2010, 41(5):1001-1007.

322. Diansan S, Shifen Z, Zhen G, Heming W, Xiangrui W: Resection of the nerves bundle from the sphenopalatine ganglia tend to increase the infarction volume following middle cerebral artery occlusion. Neurol Sci 2010, 31(4):431-435.

323. Batra A, Latour LL, Ruetzler CA, Hallenbeck JM, Spatz M, Warach S, Henning EC: Increased plasma and tissue MMP levels are associated with BCSFB and BBB disruption evident on post-contrast FLAIR after experimental stroke. J Cereb Blood Flow Metab 2010, 30(6):1188-1199.

324. Prajapati KD, Sharma SS, Roy N: Upregulation of albumin expression in focal ischemic rat brain. Brain Res 2010, 1327:118-124.

325. Chen SJ, Chang CM, Tsai SK, Chang YL, Chou SJ, Huang SS, Tai LK, Chen YC, $\mathrm{Ku} \mathrm{HH}$, Li HY, et al: Functional improvement of focal cerebral ischemia injury by subdural transplantation of induced pluripotent stem cells with fibrin glue. Stem Cells Dev 2010, 19(11):1757-1767.

326. Maddahi A, Edvinsson L: Cerebral ischemia induces microvascular proinflammatory cytokine expression via the MEK/ERK pathway. J Neuroinflammation 2010, 7:14

327. Wang GH, Jiang ZL, Chen ZQ, Li X, Peng LL: Neuroprotective effect of Lserine against temporary cerebral ischemia in rats. J Neurosci Res 2010, 88(9):2035-2045.

328. Shang J, Deguchi K, Yamashita T, Ohta Y, Zhang H, Morimoto N, Liu N Zhang $X$, Tian F, Matsuura T, et al: Antiapoptotic and antiautophagic effects of glial cell line-derived neurotrophic factor and hepatocyte growth factor after transient middle cerebral artery occlusion in rats. J Neurosci Res 2010, 88(10):2197-2206.

329. Srivastava AK, Dohare P, Ray M, Panda G: Design, synthesis and biological evaluation of new ionone derivatives as potential neuroprotective agents in cerebral ischemia. Eur J Med Chem 2010, 45(5):1964-1971.

330. Cui L, Zhang X, Yang R, Wang L, Liu L, Li M, Du W: Neuroprotection of early and short-time applying atorvastatin in the acute phase of cerebral ischemia: down-regulated 12/15-LOX, p38MAPK and CPLA2 expression, ameliorated BBB permeability. Brain Res 2010, 1325:164-173.

331. Chen C, Ostrowski RP, Zhou C, Tang J, Zhang JH: Suppression of hypoxiainducible factor-1alpha and its downstream genes reduces acute hyperglycemia-enhanced hemorrhagic transformation in a rat model of cerebral ischemia. J Neurosci Res 2010, 88(9):2046-2055.

332. Ya BL, Li CY, Zhang L, Wang W, Li L: Cornel iridoid glycoside inhibits inflammation and apoptosis in brains of rats with focal cerebral ischemia. Neurochem Res 2010, 35(5):773-781.

333. Bu Y, Kwon S, Kim YT, Kim MY, Choi H, Kim JG, Jamarkattel-Pandit N, Dore S, Kim SH, Kim H: Neuroprotective effect of HT008-1, a prescription of traditional Korean medicine, on transient focal cerebral ischemia model in rats. Phytother Res 2010, 24(8):1207-1212.

334. Adibhatla RM, Hatcher JF: Protection by D609 through cell-cycle regulation after stroke. Mol Neurobiol 2010, 41(2-3):206-217.

335. Prongay KD, Lewis AD, Hurn PD, Murphy SJ: Dietary soy may not confound acute experimental stroke infarct volume outcomes in ovariectomized female rats. Lab Anim 2010, 44(3):238-246.

336. Rink C, Roy S, Khan M, Ananth P, Kuppusamy P, Sen CK, Khanna S: Oxygensensitive outcomes and gene expression in acute ischemic stroke. J Cereb Blood Flow Metab 2010, 30(7):1275-1287.

337. Ye XH, Wu Y, Guo PP, Wang J, Yuan SY, Shang Y, Yao SL: Lipoxin A4 analogue protects brain and reduces inflammation in a rat model of focal cerebral ischemia reperfusion. Brain Res 2010, 1323:174-183.

338. Kang KA, Shin ES, Hur J, Hasan MR, Lee H, Park HJ, Park HK, Kim YJ: Acupuncture attenuates neuronal cell death in middle cerebral 
artery occlusion model of focal ischemia. Neurol Res 2010, 32(Suppl 1):84-87.

339. Tang NY, Liu CH, Hsieh CT, Hsieh CL: The anti-inflammatory effect of paeoniflorin on cerebral infarction induced by ischemia-reperfusion injury in Sprague-Dawley rats. Am J Chin Med 2010, 38(1):51-64.

340. Lu J, Cheng C, Zhao X, Liu Q, Yang P, Wang Y, Luo G: PEG-scutellarin prodrugs: synthesis, water solubility and protective effect on cerebral ischemia/reperfusion injury. Eur J Med Chem 2010, 45(5):1731-1738.

341. Sun M, Zhao Y, Gu Y, Xu C: Neuroprotective actions of aminoguanidine involve reduced the activation of calpain and caspase- 3 in a rat model of stroke. Neurochem Int 2010, 56(4):634-641.

342. Wang J, Jiang C, Liu C, Li X, Chen N, Hao Y: Neuroprotective effects of progesterone following stroke in aged rats. Behav Brain Res 2010, 209(1):119-122.

343. Gao F, Wang S, Guo Y, Wang J, Lou M, Wu J, Ding M, Tian M, Zhang H: Protective effects of repetitive transcranial magnetic stimulation in a rat model of transient cerebral ischaemia: a microPET study. Eur J Nucl Med Mol Imaging 2010, 37(5):954-961.

344. Ishii T, Asai T, Urakami T, Oku N: Accumulation of macromolecules in brain parenchyma in acute phase of cerebral infarction/reperfusion. Brain Res 2010, 1321:164-168.

345. Zwagerman N, Sprague S, Davis MD, Daniels B, Goel G, Ding Y: Preischemic exercise preserves cerebral blood flow during reperfusion in stroke. Neurol Res 2010, 32(5):523-529.

346. Yamane K, Kitamura Y, Yanagida T, Takata K, Yanagisawa D, Taniguchi T, Taira T, Ariga H: Oxidative neurodegeneration is prevented by UCP0045037, an allosteric modulator for the reduced form of DJ-1, a wild-type of familial Parkinson's disease-linked PARK7. Int J Mol Sci 2009, 10(11):4789-4804.

347. David HN, Haelewyn B, Risso JJ, Colloc'h N, Abraini JH: Xenon is an inhibitor of tissue-plasminogen activator: adverse and beneficial effects in a rat model of thromboembolic stroke. J Cereb Blood Flow Metab 2010, 30(4):718-728.

348. Sang N, Yun Y, Li H, Hou L, Han M, Li G: SO2 inhalation contributes to the development and progression of ischemic stroke in the brain. Toxicol Sci 2010, 114(2):226-236.

349. Liebelt B, Papapetrou P, Ali A, Guo M, Ji X, Peng C, Rogers R, Curry A, Jimenez D, Ding Y: Exercise preconditioning reduces neuronal apoptosis in stroke by up-regulating heat shock protein-70 (heat shock protein-72) and extracellular-signal-regulated-kinase 1/2. Neuroscience 2010, 166(4): 1091-1100.

350. Ruscher K, Erickson A, Kuric E, Inacio AR, Wieloch T: Effects of chronic Clozapine administration on apolipoprotein D levels and on functional recovery following experimental stroke. Brain Res 2010, 1321:152-163.

351. Zhan X, Ander BP, Liao $\mid H$, Hansen JE, Kim C, Clements D, Weisbart RH, Nishimura RN, Sharp FR: Recombinant Fv-Hsp70 protein mediates neuroprotection after focal cerebral ischemia in rats. Stroke 2010, 41(3):538-543.

352. Zhu H, Fan X, Yu Z, Liu J, Murata Y, Lu J, Zhao S, Hajjar KA, Lo EH, Wang X: Annexin A2 combined with low-dose tPA improves thrombolytic therapy in a rat model of focal embolic stroke. J Cereb Blood Flow Metab 2010, 30(6):1137-1146.

353. Rewell SS, Fernandez JA, Cox SF, Spratt NJ, Hogan L, Aleksoska E, van Raay L, Liberatore GT, Batchelor PE, Howells DW: Inducing stroke in aged, hypertensive, diabetic rats. J Cereb Blood Flow Metab 2010, 30(4):729-733

354. Abu Fanne R, Nassar T, Yarovoi S, Rayan A, Lamensdorf I, Karakoveski M, Vadim P, Jammal M, Cines DB, Higazi AA: Blood-brain barrier permeability and tPA-mediated neurotoxicity. Neuropharmacology 2010, 58(7):972-980

355. Song M, Kim YJ, Kim YH, Roh J, Kim SU, Yoon BW: Using a neodymium magnet to target delivery of ferumoxide-labeled human neural stem cells in a rat model of focal cerebral ischemia. Hum Gene Ther 2010, 21(5):603-610.

356. Zacharek A, Shehadah A, Chen J, Cui X, Roberts C, Lu M, Chopp M: Comparison of bone marrow stromal cells derived from stroke and normal rats for stroke treatment. Stroke 2010, 41(3):524-530.

357. Liu C, Wu J, Xu K, Cai F, Gu J, Ma L, Chen J: Neuroprotection by baicalein in ischemic brain injury involves PTEN/AKT pathway. J Neurochem 2010, 112(6):1500-1512

358. Cao W, Shah HP, Glushakov AV, Mecca AP, Shi P, Sumners C, Seubert CN Martynyuk AE: Efficacy of 3,5-dibromo-L-phenylalanine in rat models of stroke, seizures and sensorimotor gating deficit. Br J Pharmacol 2009, 158(8):2005-2013.

359. Moldovan M, Constantinescu AO, Balseanu A, Oprescu N, Zagrean L, PopaWagner A: Sleep deprivation attenuates experimental stroke severity in rats. Exp Neurol 2010, 222(1):135-143.

360. Swanson RA, Morton MT, Tsao-Wu G, Savalos RA, Davidson C, Sharp FR: A semiautomated method for measuring brain infarct volume. J Cereb Blood Flow Metab 1990, 10(2):290-293.

361. Leach MJ, Swan JH, Eisenthal D, Dopson M, Nobbs M: BW619C89, a glutamate release inhibitor, protects against focal cerebral ischemic damage. Stroke 1993, 24(7):1063-1067.

362. Schlattmann P, Dirnagl U: Statistics in experimental cerebrovascular research-comparison of two groups with a continuous outcome variable. J Cereb Blood Flow Metab 2010, 30(3):474-479.

363. Strom JO, Strid T, Hammarstrom S: Disruption of the alox5ap gene ameliorates focal ischemic stroke: possible consequence of impaired leukotriene biosynthesis. BMC Neurosci 2012, 13:146.

364. Hom S, Fleegal MA, Egleton RD, Campos CR, Hawkins BT, Davis TP: Comparative changes in the blood-brain barrier and cerebral infarction of SHR and WKY rats. Am J Physiol Regul Integr Comp Physiol 2007, 292(5):R1881-R1892

365. Dogan A, Baskaya MK, Rao VL, Rao AM, Dempsey RJ: Intraluminal suture occlusion of the middle cerebral artery in Spontaneously Hypertensive rats. Neurol Res 1998, 20(3):265-270.

366. Brint $S$, Jacewicz M, Kiessling M, Tanabe J, Pulsinelli W: Focal brain ischemia in the rat: methods for reproducible neocortical infarction using tandem occlusion of the distal middle cerebral and ipsilateral common carotid arteries. J Cereb Blood Flow Metab 1988 8(4):474-485

367. Duverger D, Mackenzie ET: The quantification of cerebral infarction following focal ischemia in the rat: influence of strain, arterial pressure, blood glucose concentration, and age. J Cereb Blood Flow Metab 1988, 8(4):449-461.

368. Aspey BS, Cohen S, Patel Y, Terruli M, Harrison MJ: Middle cerebral artery occlusion in the rat: consistent protocol for a model of stroke. Neuropathol Appl Neurobiol 1998, 24(6):487-497.

369. Dittmar MS, Vatankhah B, Fehm NP, Schuierer G, Bogdahn U, Horn M, Schlachetzki F: Fischer-344 rats are unsuitable for the MCAO filament model due to their cerebrovascular anatomy. J Neurosci Meth 2006, 156(1-2):50-54.

370. Prieto R, Carceller F, Roda JM, Avendano C: The intraluminal thread model revisited: rat strain differences in local cerebral blood flow. Neurol Res 2005, 27(1):47-52.

371. Walberer M, Stolz E, Muller C, Friedrich C, Rottger C, Blaes F, Kaps M, Fisher M, Bachmann G, Gerriets T: Experimental stroke: ischaemic lesion volume and oedema formation differ among rat strains (a comparison between Wistar and Sprague-Dawley rats using MRI). Lab Anim 2006, 40(1):1-8.

372. McCabe C, Gallagher L, Gsell W, Graham D, Dominiczak AF, Macrae IM: Differences in the evolution of the ischemic penumbra in stroke-prone spontaneously hypertensive and Wistar-Kyoto rats. Stroke 2009, 40(12):3864-3868.

373. Bardutzky J, Shen Q, Henninger N, Bouley J, Duong TQ, Fisher M: Differences in ischemic lesion evolution in different rat strains using diffusion and perfusion imaging. Stroke 2005, 36(9):2000-2005.

374. Kanemitsu H, Nakagomi T, Tamura A, Tsuchiya T, Kono G, Sano K: Differences in the extent of primary ischemic damage between middle cerebral artery coagulation and intraluminal occlusion models. $J$ Cereb Blood Flow Metab 2002, 22(10):1196-1204

375. Bouley J, Fisher M, Henninger N: Comparison between coated vs. uncoated suture middle cerebral artery occlusion in the rat as assessed by perfusion/diffusion weighted imaging. Neurosci Lett 2007, 412(3):185-190

376. Laing RJ, Jakubowski J, Laing RW: Middle cerebral artery occlusion without craniectomy in rats. Which method works best? Stroke 1993, 24(2):294-297. discussion 297-298.

377. Spratt NJ, Fernandez J, Chen M, Rewell S, Cox S, van Raay L, Hogan L, Howells DW: Modification of the method of thread manufacture improves stroke induction rate and reduces mortality after threadocclusion of the middle cerebral artery in young or aged rats. $J$ Neurosci Meth 2006, 155(2):285-290. 
378. Bavik CO, Eriksson U, Allen RA, Peterson PA: Identification and partial characterization of a retinal pigment epithelial membrane receptor for plasma retinol-binding protein. J Biol Chem 1991, 266(23):14978-14985.

379. Lourbopoulos A, Karacostas D, Artemis N, Milonas I, Grigoriadis N: Effectiveness of a new modified intraluminal suture for temporary middle cerebral artery occlusion in rats of various weight. J Neurosci Meth 2008, 173(2):225-234.

380. Kuge Y, Minematsu K, Yamaguchi T, Miyake Y: Nylon monofilament for intraluminal middle cerebral artery occlusion in rats. Stroke 1995, 26(9):1655-1657. discussion 1658

381. Oliff HS, Weber E, Eilon G, Marek P: The role of strain/vendor differences on the outcome of focal ischemia induced by intraluminal middle cerebral artery occlusion in the rat. Brain Res 1995, 675(1-2):20-26.

382. Sena ES, Briscoe CL, Howells DW, Donnan GA, Sandercock PA, Macleod MR: Factors affecting the apparent efficacy and safety of tissue plasminogen activator in thrombotic occlusion models of stroke: systematic review and meta-analysis. J Cereb Blood Flow Metab 2010, 30(12):1905-1913.

doi:10.1186/1471-2202-14-41

Cite this article as: Ström et al:: Method parameters' impact on mortality and variability in rat stroke experiments: a meta-analysis. BMC Neuroscience 2013 14:41.

\section{Submit your next manuscript to BioMed Central and take full advantage of:}

- Convenient online submission

- Thorough peer review

- No space constraints or color figure charges

- Immediate publication on acceptance

- Inclusion in PubMed, CAS, Scopus and Google Scholar

- Research which is freely available for redistribution 